\title{
Dirhodium(II) Carbenes : The Chiral Product Cascade
}

\author{
*Gregory H. P. Roos, **Conrad E. Raab and *Said Al-Hatmi \\ "Chemistry Department, College of Science, Sultan Qaboos University, \\ P.O. Box 36, Al-Khod 123, Muscat, Sultanate of Oman \\ ** Department of Drug Metabolism, Merck and Co., Inc., RY80R -104, \\ P. O. Box 2000, Rahway, New Jersey 07065, USA.
}

\section{كارينات دليرويم (r) ـ نسج الناتج الكليرالي}

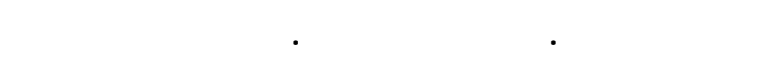

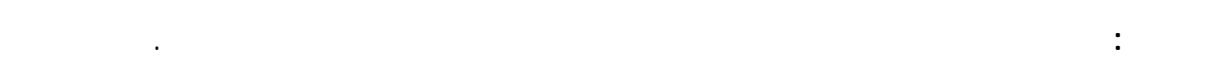



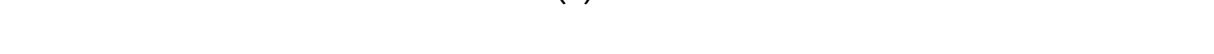

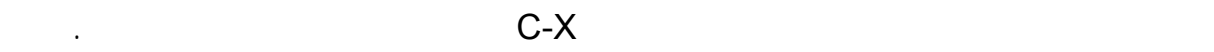

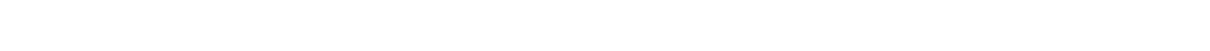

. نوئي

\begin{abstract}
The last decade has witnessed enormous growth in the spectrum of highly efficient asymmetric synthetic transformations. One prominent example of this progress is the application of dirhodium (II) carbenes generated from diazoprecursors. Innovative construction of 'designer' catalysts has played a integral role in extending the breadth of the synthetic cascade of non-racemic products now available through the range of cyclopropanation, C-X insertion, aromatic cycloaddition-rearrangement, and ylide-based reaction types. This review deals briefly with an overview of the important catalytic systems and maintains as its primary focus the cascade of diverse optically enriched products that flow from their applications.
\end{abstract}




\section{CONTENTS}

1. Introduction 74

1.1 The Need for Asymmetric Synthesis 74

1.2 Carbene Reactions $\quad 74$

2. Generation of Dirhodium(II) Carbenes 75

2.1 Diazo Compounds $\quad 75$

2.2 Metal-Catalysed Diazo Decomposition $\quad 76$

$\begin{array}{ll}2.3 \text { Dirhodium(II) Catalysts } & 76\end{array}$

3. Reaction Products From Dirhodium(II) Carbenes $\quad 80$

$\begin{array}{lll}3.1 \text { Cyclopropanes and Cyclopropenes } & 80\end{array}$

3.2 Intermolecular Processes $\quad 81$

$\begin{array}{ll}3.3 \text { Intramolecular Processes } & 87\end{array}$

$\begin{array}{ll}3.4 \text { Insertion Products } & 92\end{array}$

3.4.1 Carbon-Hydrogen Insettion Products 94

3.4.2 Heteroatom-Hydrogen Insertion Products 100

$\begin{array}{ll}\text { 3.5 Aromatic Cycloaddition and Substitution Products } & 101\end{array}$

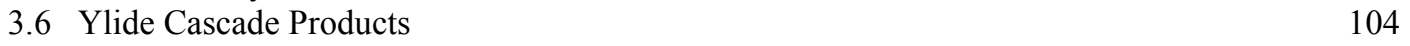

4. Conclusion 105

5. References 106

\section{Introduction}

\subsection{The Need for Asymmetric Synthesis}

The world around us is chiral. Most organic compounds are chiral. The chemistry of perfumes, nutrients, pesticides, and pharmaceuticals involves chiral compounds whose physiological or pharmacological properties depend upon their recognition by chiral receptors. Public opinion and associated legislation surrounding the pharmaceutical industry demands, especially since the thalidomide disaster (Figure 1), the preparation and testing of enantiopure compounds. This has, in part, caused asymmetric synthesis to become the single greatest "growth industry" within organic chemistry over the past 25 years. Once the important factors that control reaction stereoselectivity were recognized, development has exploded throughout the arena of organic synthesis (Ager and East, 1996; Gawley and Aubé, 1996; Seyden-Penne, 1995).

Of the handful of approaches to asymmetric synthesis, catalysis has the advantage over stoichiometric synthesis with chirons (enantiomerically pure substrate fragments) or chiral auxiliaries (temporary enantiomerically pure attachments), particularly in terms of large-scale or industrial processes. Catalytic asymmetric reactions have been the subject of research investigations for many years and, particularly over the last decade, the number of catalytic asymmetric processes (some giving enantioselectivities of greater than 99\%) has burgeoned (Brünner and Zettlmeier, 1993; Jacobsen et al, 1999). Whilst broad scope and high enantioselectivity are important for any catalytic asymmetric transformation, they alone are not necessarily sufficient to ensure that a process will become widely used, especially on industrial scale. To reach this goal, the process additionally needs to be economical and easy to perform. For this reason, many of the new wave of catalysts are either already commercially available, or are designed for easy or in situ preparation.

\subsection{Carbene Reactions}

The general group of transformations referred to as "carbene reactions" forms a versatile class of transition metal catalysed processes. These reactions are characterised by the involvement of a transition 


\section{DIRHODIUM(II) CARBENES: THE CHIRAL PRODUCT CASCADE}

metal stabilized carbene that is formed from the decomposition of a diazo compound in the presence of the transition metal catalyst. Further reaction of the carbene may follow a number of pathways including insertion and addition reactions, as well as ylide generation. Recent investigations have focussed on the development of catalysts that control the selectivity of what had traditionally been thought of as nonselective reactions of "free carbenes". Of these, dirhodium catalysts have emerged as arguably the most versatile for a wide range of stereoselective transformations (Doyle et al, 1993a, 1994a, 1996a, 1997a, 1998a, 1998b, 1998c, 1999; Ene and Doyle, 1998; Ye and McKervey, 1994; Roos and Raab, 1997). Given the rapid growth within this area of endeavor, this review seeks to place these developments in context via the published literature through mid-1999. The specific focus is on homochiral catalysts and therefore excludes chiron-based syntheses, and only pertinent examples of diastereoselectivty via chiral auxiliaries are covered. Previous reviews have tended to focus on details of catalyst development or of subsequent reaction type that the carbene undergoes. Outside of essential introductory material, this review seeks primarily to highlight the wealth of diverse enantiomerically enriched chiral products that are available via the numerous highly chemoselective, regioselective, and stereoselective transformations brought about by dirhodium(II) catalyst systems. Some of these have a high potential for commercial adaptation. Readers seeking further details on access to diazo compounds, catalyst design and preparation, as well as mechanistic aspects are referred to the alternative specialist reviews cited throughout.<smiles>O=C1CCC(N2C(=O)c3ccccc3C2=O)C(=O)N1</smiles>

(R)-Thalidomide Sedative<smiles>O=C1CCC(N2C(=O)c3ccccc3C2=O)C(=O)N1</smiles>

(S)-Thalidomide Teratogenic

Figure 1. Thalidomide enantiomers

\section{Generation of Dirhodium(II) Carbenes}

\subsection{Diazo Compounds}

Diazo compounds are derivatives of diazomethane, and as such have stabilities and reactivities that reflect their substituents. Generally, the stabilities of diazo compounds towards diazo decomposition are increased by electron withdrawing substituents, and decreased by electron donating substituents (Figure 2). For this reason, the most widely employed diazo compounds for metal catalysed reactions are diazocarbonyl compounds. Numerous synthetic methodologies are now available for the synthesis of diazo compounds and these have been reviewed by Regitz and Maas (1986) and Doyle et al (1998a). 


\subsection{Metal-Catalysed Diazo Decomposition}

Since diazo decomposition is an acid promoted process, transition metal complexes that are effective catalysts for diazo decomposition are of necessity Lewis acids (Doyle, 1986). Their catalytic activity depends on the metal centre being coordinatively unsaturated, which allows them to react as electrophiles with diazo compounds.

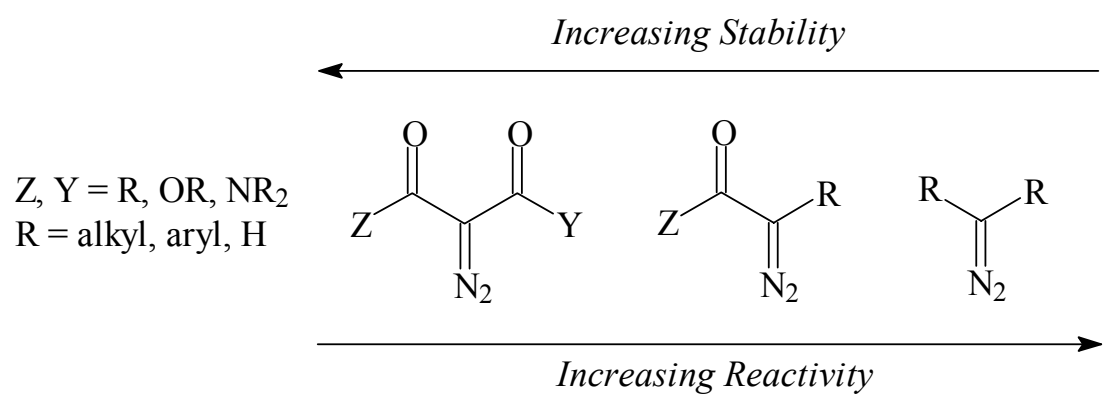

Figure 2. Relative stability/reactivity of diazo substrates

In the generally accepted mechanism for catalytic diazo decomposition, electrophilic addition of the catalyst to the diazo compound causes the loss of dinitrogen from a diazonium ion adduct $\mathbf{1}$ to produce a metal-stabilized carbene 2 (Scheme 1). The electrophilic carbene is transferred to an electron-rich substrate (S:) to form the product of the carbene reaction $\left(\mathrm{SCR}_{2}\right)$, with release of the transition metal catalyst to complete the catalytic cycle.

\subsection{Dirhodium(II) Catalysts}

A wide range of other metals such as copper, cobalt, palladium, ruthenium, osmium, iron, nickel, and zinc have been employed with varying success in catalytic systems (Roos and Raab, 1997; Doyle et $a l, 1998$ a). Rhodium, and more specifically dirhodium(II) complexes have proven to be the most effective and versatile catalysts for diazo decomposition (Maas, 1987; Padwa and Krumpe, 1992; Davies, 1993a; Padwa and Austin, 1994; Ye and McKervey, 1994; Doyle, 1995a). Generally, rhodium-mediated carbene reactions proceed under much milder conditions than is common for classical synthetic methodology with copper(II) catalysts (Padwa and Austin, 1994).

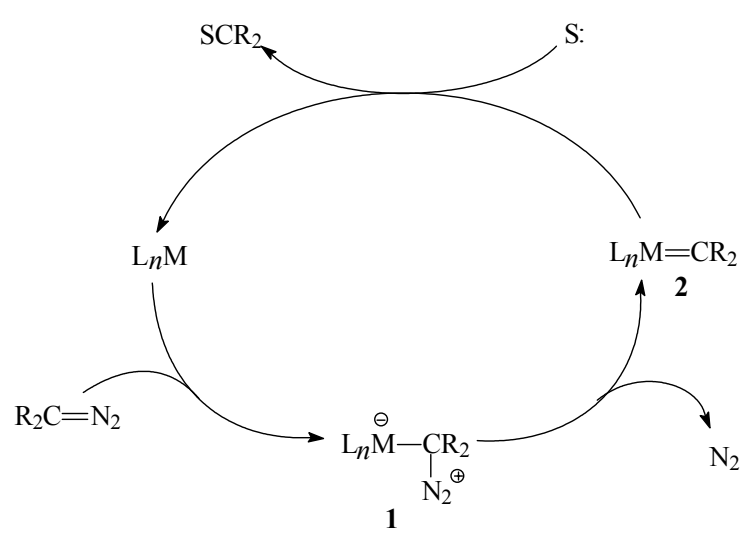

Scheme 1. Cycle for transition-metal catalyzed diazo decomposition 
Their versatility arises from the large variety of bridging ligands that can be coordinated to the dirhodium(II) skeleton, and in their marked influence on reactivity and selectivity. Dirhodium(II) catalyst complexes are divided into two major groups, those bridged with carboxylate ligands and those bridged with carboxamidate ligands. It is through the tuning of these ligands that particular catalysts are able to provide appropriate chemical properties as well as specific reactivity and selectivity profiles for desired transformations. The dirhodium(II) catalysts are based on the parent dirhodium(II) tetraacetate, $\mathrm{Rh}_{2}(\mathrm{OAc})_{4} 3$, first introduced by Paulissenen et al (1973). Since that time, this has been the single most widely used catalyst for metal carbene transformations. $\mathrm{Rh}_{2}(\mathrm{OAc})_{4} 3$ possesses four bridging acetate ligands and has $\mathrm{D}_{4 h}$ symmetry, leaving one vacant axial coordination site on each metal for carbene attachment (Boyar and Robinson, 1983). A multitude of dirhodium(II) catalysts is available by replacement of the acetate ligands with other carboxylate or carboxamidate ligands. Many of these catalysts have unique properties or synthetic uses (Doyle et al, 1998a, 1998b).

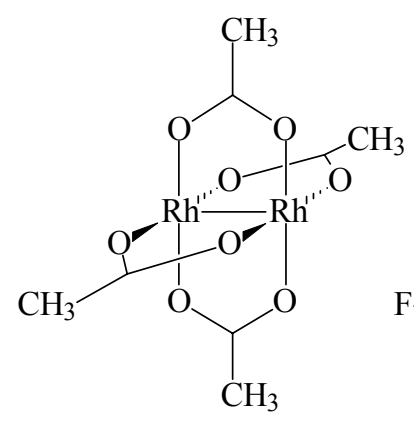

$\mathrm{Rh}_{2}(\mathrm{OAc})_{4} 3$

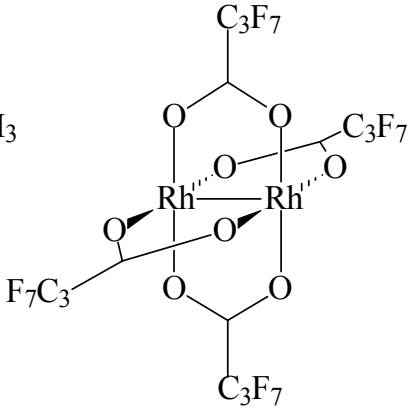

$\mathrm{Rh}_{2}(\mathrm{pfb})_{4} 4$

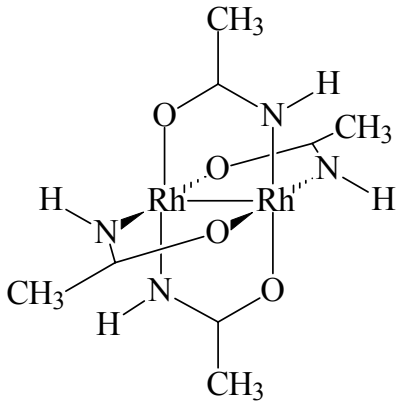

$\mathrm{Rh}_{2}(\text { acam })_{4} \mathbf{5}$<smiles>[R]C([R2])C(O[R](C)(C)C)O[R](C)(C)C</smiles>

6

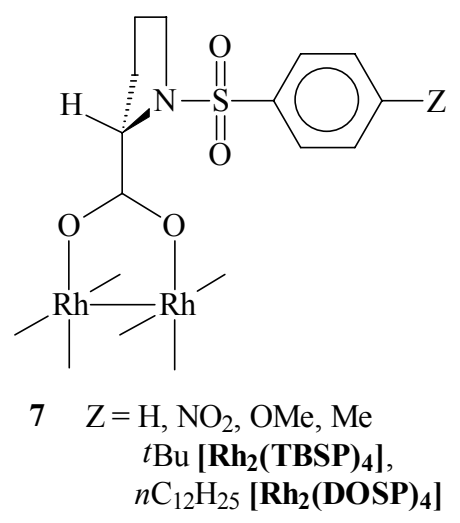<smiles>[R][C@]([2H])(C(O[R](C)(C)C)O[R](C)(C)C)N1C(=O)c2ccccc2C1=O</smiles>

$8 \mathrm{R}=\mathrm{PhCH}_{2}, t \mathrm{Bu}$

Dirhodium(II) perfluorobutyrate, $\mathrm{Rh}_{2}(\mathrm{pfb})_{4} \mathbf{4}$, is the most reactive dirhodium(II) catalyst, and its selectivity in diazo decomposition reactions is often correspondingly poor (Doyle et al, 1993b). In contrast, dirhodium(II) carboxamidates such as $\mathrm{Rh}_{2}(\text { acam })_{4} \mathbf{5}$, which have two nitrogen and two oxygen donor atoms at each rhodium, with the two nitrogens arranged cis to each other (a [2,2-cis] configuration) 
(Ahsan et al, 1986) are less reactive than the dirhodium(II) carboxylates in diazo decomposition, but are often more selective in the subsequent carbene reactions (Doyle et al, 1989a,b; Doyle et al, 1991a).

Homochiral dirhodium(II) carboxylate catalysts $\mathbf{6}$ for asymmetric carbene reactions were simultaneously developed in three laboratories (Brunner et al, 1989; Kennedy et al, 1990; Hashimoto et al, 1990; Roos and McKervey, 1992) from enantiomerically pure carboxylic acids. More recent refinements have demonstrated highly successful prolinate 7 (McKervey and Ye, 1992; Davies et al, 1993b, 1996; Doyle et al, 1996b) and phthalimide 8 derivatives (Hashimoto et al, 1994; Watanabe et al, 1995, 1996a). A recent report (Buck et al, 1998) has employed parallel array techniques to screen rapidly for novel carboxylate catalysts.

In contrast to the dirhodium(II) carboxylates, the rhodium(II) carboxamidates allow placement of an inducing chiral centre adjacent to nitrogen in closer proximity to the axial carbene centre. A series of more than twenty structurally varied homochiral dirhodium(II) carboxamidates derived from chiral cyclic amide ligands has been developed by Doyle and co-workers (Doyle, 1994b, 1996a). In general, dirhodium(II) carboxamidate catalysts based on chiral 2-oxopyrrolidine 9 (Doyle et al, 1993c, 1994c) 2oxazolidinone 10 (Doyle et al, 1993d, 1995b), $N$-acylimidazolidinone 11 (Doyle, 1995c, 1996c, 1997b; Roos et al, 1998), and 2-azetidinone 12 (Doyle et al, 1996d) ligands, especially those bearing pendant carboxylate groups, afford the highest levels of enantioselectivity.

Dirhodium(II) complexes 13 bearing chiral phosphate ligands derived from binaphthol have been reported to provide moderate enantioselectivities in a number of carbene reactions (McCarthy et al, 1992; Pirrung and Zhang, 1992). In addition, Estevan et al (1995) prepared a novel set of $\mathrm{C}_{2}$-symmetric catalysts 14 bearing two cis carboxylate ligands along with two orthometallated phosphine ligands.



Aromatic cycloaddition

Scheme 2. Diversity of metal carbene reactions 
<smiles>N[R17](N)(O)N1C2CC[C@H](I)O[N+](N)(O)O[N+]21O</smiles>

a $\mathrm{A}=\mathrm{CO}_{2} \mathrm{Me} ; \mathrm{Rh}_{2}(5 S-\mathrm{MEPY})_{4}$

b $\mathrm{A}=\mathrm{CO}_{2} \mathrm{CH}_{2} \mathrm{CMe}_{3} ; \mathrm{Rh}_{2}(5 S \text {-NEPY })_{4}$

c $\mathrm{A}=\mathrm{CO}_{2}\left(\mathrm{CH}_{2}\right)_{17} \mathrm{Me} ; \mathrm{Rh}_{2}(5 S \text {-ODPY })_{4}$

d $\mathrm{A}=\mathrm{CONMe}_{2} ; \mathrm{Rh}_{2}(5 S \text {-DMAP })_{4}$

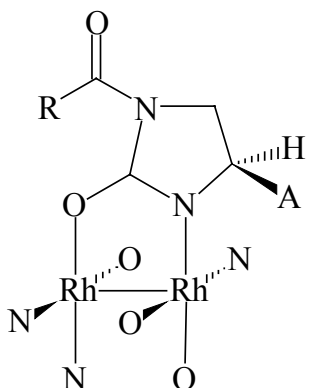

11

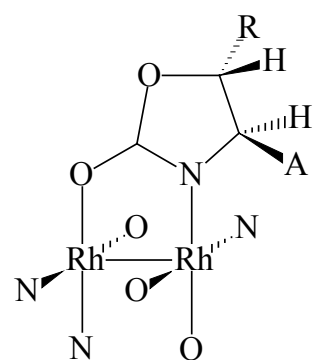

10

a $\mathrm{A}=\mathrm{CO}_{2} \mathrm{Me}, \mathrm{R}=\mathrm{H} ; \mathrm{Rh}_{2}(4 S-\mathrm{MEOX})_{4}$

b $\mathrm{A}=\mathrm{CO}_{2} \mathrm{Me}, \mathrm{R}=\mathrm{CH}_{3} ; \mathrm{Rh}_{2}(4 S-\mathrm{THREOX})_{4}$

c $\mathrm{A}=\mathrm{CH}_{2} \mathrm{Ph}, \mathrm{R}=\mathrm{H} ; \mathrm{Rh}_{2}(4 R-\mathrm{BNOX})_{4}$

d $\mathrm{A}=i \mathrm{Pr}, \mathrm{R}=\mathrm{H} ; \mathrm{Rh}_{2}(4 R-\mathrm{IPOX})_{4}$

e $\mathrm{A}=\mathrm{Ph}, \mathrm{R}=\mathrm{H} ; \mathrm{Rh}_{2}(4 R-\mathrm{PHOX})_{4}$

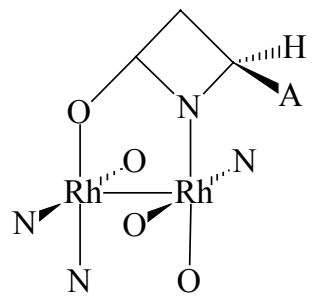

12

a $\mathrm{A}=\mathrm{CO}_{2} \mathrm{Me}, \mathrm{R}=\mathrm{CH}_{3} ; \mathrm{Rh}_{2}(4 S \text {-MACIM })_{4}$

b $\mathrm{A}=\mathrm{CO}_{2} \mathrm{Me}, \mathrm{R}=\mathrm{Ph} ; \mathrm{Rh}_{2}(4 S-\mathrm{MBOIM})_{4}$

a $\mathrm{A}=\mathrm{CO}_{2} \mathrm{CH}_{2} \mathrm{Ph} ; \mathrm{Rh}_{2}(4 S \text {-BNAZ })_{4}$

b $\mathrm{A}=\mathrm{CO}_{2} \mathrm{CH}_{2} \mathrm{CHMe}_{2} ; \mathrm{Rh}_{2}(4 S \text {-IBAZ })_{4}$

c $\mathrm{A}=\mathrm{CO}_{2} \mathrm{Me}, \mathrm{R}=\mathrm{PhCH}_{2} ; \mathrm{Rh}_{2}(4 S \text {-MPAIM })_{4}$

d $\mathrm{A}=\mathrm{CO}_{2} \mathrm{Me}, \mathrm{R}=\mathrm{PhCH}_{2} \mathrm{CH}_{2} ; \mathrm{Rh}_{2}(4 S-\mathrm{MPPIM})_{4}$

e $\mathrm{A}=\mathrm{CO}_{2} \mathrm{Me}, \mathrm{R}=c-\mathrm{C}_{6} \mathrm{H}_{11} \mathrm{CH}_{2} ; \mathrm{Rh}_{2}(4 S-\mathrm{MCHIM})_{4}$<smiles>C[R](C)(C)O[Pb](C)(C)Oc1ccc2ccccc2c1Oc1ccc2ccccc2c1O[PH](C)(C)C</smiles>

13

a. $\mathrm{Rh}_{2}(\mathrm{~S} \text {-BNHP })_{2}\left(\mathrm{HCO}_{3}\right)_{2}$

b. $\mathrm{Rh}_{2}(R-\mathrm{BNHP})_{4}$

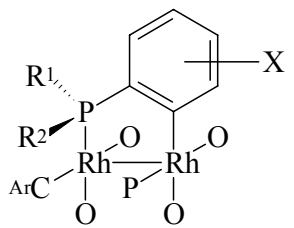

14

$\mathrm{X}=\mathrm{H}, \mathrm{F}, \mathrm{CH}_{3}, \mathrm{CF}_{3}$ 
(a)<smiles>[R]OC(=O)C=[W]</smiles>

(b)<smiles>[R]OC(=O)C=[W]</smiles>

(c)<smiles>[R]OC(=O)C=[W]</smiles>
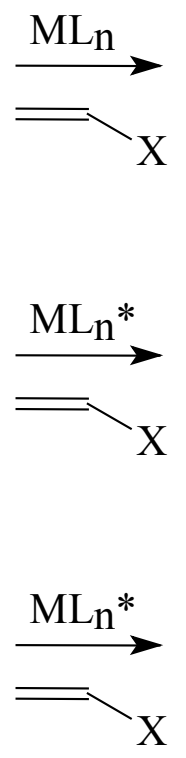<smiles>[R]OC(=O)C1C[C@H]1[X]</smiles>

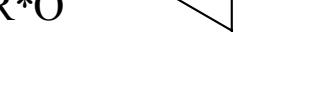<smiles>CCP</smiles><smiles>[R20]OC(=C)C1C2CC21</smiles>

Scheme 3. Approaches to asymmetric synthesis with metal carbene

\section{Reaction Products From Dirhodium(II) Carbenes}

The metal-carbenes resulting from the diazo decomposition of $\alpha$-diazocarbonyl compounds by a transition metal catalyst, are versatile electrophilic reagents. Dirhodium(II) catalysed diazo decompositions provide the greatest versatility in subsequent carbene reactions, and provide many synthetically useful transformations. This includes inter- and intramolecular reactions as diverse as cyclopropanation, cyclopropenation, insertion, aromatic cycloaddition, and ylide generation (Scheme 2). As a result, the range of stereoselectively generated product types is large.

Researchers in this area have tested a variety of fundamental approaches to the asymmetric production of chiral compounds via dirhodium(II)-catalysed reactions (Scheme 3). Thus, (a) diastereoselective reaction of achiral catalysts with diazo substrates containing chiral auxiliaries, (b) enantioselective reaction between chiral catalysts and achiral substrates, and in a few instances (c) a double diastereoselective approach with both chiral catalyst and substrate have been used. For the purpose of orderly classification, the range of product molecules has been grouped according to the reaction type via which they are generated.

\subsection{Cyclopropanes and Cyclopropenes}

Due to their biological significance and synthetic utility, cyclopropanes and cyclopropenes are extremely important target molecules (Rappoport, 1987; Binger and Büch, 1987; Baird, 1988; Salaün, 1989). They are often present as structural sub-units in natural and non-natural products (Rappoport, 1987; Burke and Grieco, 1979; Hudlicky et al, 1985; Ho, 1988; Burgess and Ho, 1994), are frequently used as mechanistic probes to elucidate reaction pathways (Suckling, 1988; Silverman et al, 1993; Newcomb and Chestney, 1994; Caldwell and Zhou, 1994; Husbands et al, 1994), and are increasingly valuable as synthetic intermediates (Wong et al, 1989; Davies, 1991; Reissig, 1995). 


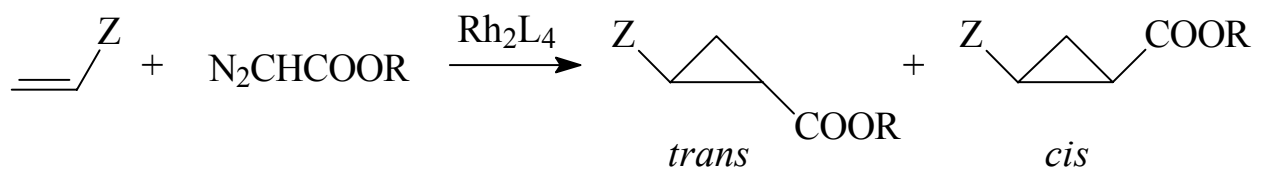

Since the availability of enantiomerically pure cyclopropanes is critical to many applications, a number of useful methods for their enantioselective synthesis have been developed. These include the cyclopropanation of chiral bicyclic lactams to give optically pure di- and trisubstituted cyclopropanes; highly diastereoselective Simmons-Smith cyclopropanation of chiral auxiliary-derivatised allylic ethers; enantioselective Simmons-Smith cyclopropanation of allylic alcohols using diethylzinc that is coordinated with chiral ligands; and enzymatic resolutions of meso-cyclopropanes. In the field of asymmetric synthesis, cyclopropanation of electron-rich olefins by catalytic diazo decomposition of $\alpha$-diazocarbonyl compounds with chiral catalysts equation 1, particularly copper and rhodium, has become an attractive and important route to optically active cyclopropanes (Maas, 1987; Doyle, 1993a, 1998a, 1998d; Ye and McKervey, 1994, Singh et al, 1997). Cyclopropanation may either be performed intermolecularly or intramolecularly. A successful example of the former is the commercial synthesis (by the "Sumitomo process") of optically pure cilastatin 15, an in vivo stabiliser of the antibiotic imipenem (Doyle, 1995a). Generally it has been found that copper-based systems are the better catalysts for intermolecular cyclopropanation with traditional diazoacetates, whilst dirhodium catalysts provide the better results in intramolecular variants (Roos and Raab, 1997; Doyle et al, 1998a).<smiles>CC1(C)CC1C(=O)N/C(=C\CCCSC[C@H](N)C(=O)O)C(=O)O</smiles><smiles>CC1C(c2ccccc2)OC(=O)N1C(=O)C=[NH2+]</smiles>

16<smiles>CC(C)[C@H]1COC(=O)N1C(=O)[NH2+][Na]</smiles>

17

\subsection{Intermolecular Processes}

Initial attempts at asymmetric intermolecular cyclopropanations by means of chiral auxiliaries bonded to diazoacetates were largely unsuccessful (equation $1, \mathrm{Z}=$ chiral auxiliary). Chiral $N$ (diazoacetyl)oxazolidinones 16 and 17 underwent $\mathrm{Rh}_{2}(\mathrm{OAc})_{4}$ catalysed cyclopropanation of styrene in 
good yield but with low diastereoselectivity (Doyle et al, 1990). High diastereoselectivities in the catalytic cyclopropanation of diazo compounds bearing chiral auxiliaries have only been achieved in select cases (Davies et al, 1993c; Doyle et al, 1993e). These reports now include diastereomeric excesses of up to $97 \%$ in the dirhodium(II) octanoate catalysed cyclopropanation of styrenes and vinyl ethers with $(R)$ pantolactone- and $(S)$-lactate-substituted vinyldiazomethane 18 with (Table 1) (Davies et al, 1993c, 1997a) These workers (Davies et al, 1998a) have shown that appropriate choice of vinyldiazo substituent allows facile subsequent transformation of the cyclopropyl products to 2,3-dihydrofurans with high asymmetric induction.

Table 1. Diastereoselective intermolecular cyclopropanation with vinyldiazoacetates containing chiral auxiliaries.<smiles></smiles>

18

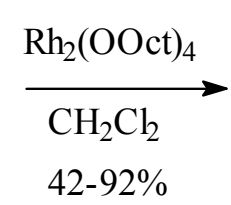

b $\mathrm{X}=$

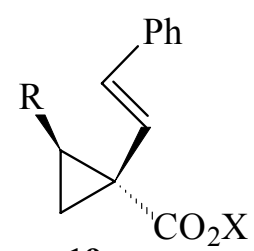

19 a $\mathrm{X}=$<smiles>CC[C@H]1C(=O)OCC1(C)C</smiles><smiles>[X]#CC[C@@H](C)C(=O)OCC</smiles>

\begin{tabular}{|c|c|c|c|}
\hline $\mathbf{R}$ & Diazo & de, \% & Abs. config. \\
\hline $\mathrm{Ph}$ & $\mathbf{1 8 a}$ & 89 & $(1 \mathrm{R}, 2 \mathrm{R})$ \\
$\mathrm{Ph}$ & $\mathbf{1 8 a}$ & 97 & $(1 \mathrm{R}, 2 \mathrm{R})$ \\
$\mathrm{pClC}_{6} \mathrm{H}_{4}$ & $\mathbf{1 8 a}$ & $>95$ & $(1 \mathrm{R}, 2 \mathrm{R})$ \\
$\mathrm{pMeOC}_{6} \mathrm{H}_{4}$ & $\mathbf{1 8 a}$ & $>95$ & $(1 \mathrm{R}, 2 \mathrm{R})$ \\
$\mathrm{AcO}$ & $\mathbf{1 8 a}$ & 90 & - \\
$\mathrm{EtO}$ & $\mathbf{1 8 a}$ & 92 & - \\
$\mathrm{Ph}$ & $\mathbf{1 8 b}$ & 67 & $(1 \mathrm{~S}, 2 \mathrm{~S})$ \\
\hline
\end{tabular}

This methodology has been extended to diene systems, furans (Davies et al, 1996b) to give 8oxabicyclo[3.2.1] octan-3-ones and pyrroles (Davies et al, 1997b) to give tropanes (Scheme 4). The fundamental reaction sequence has allowed the preparation of the oxabicycles 20-22 and a series of $2 \beta$ acyl-3 $\beta$-aryltropanes 23 (Davies et al, 1994a, 1996c), which are important building blocks in further synthesis. 

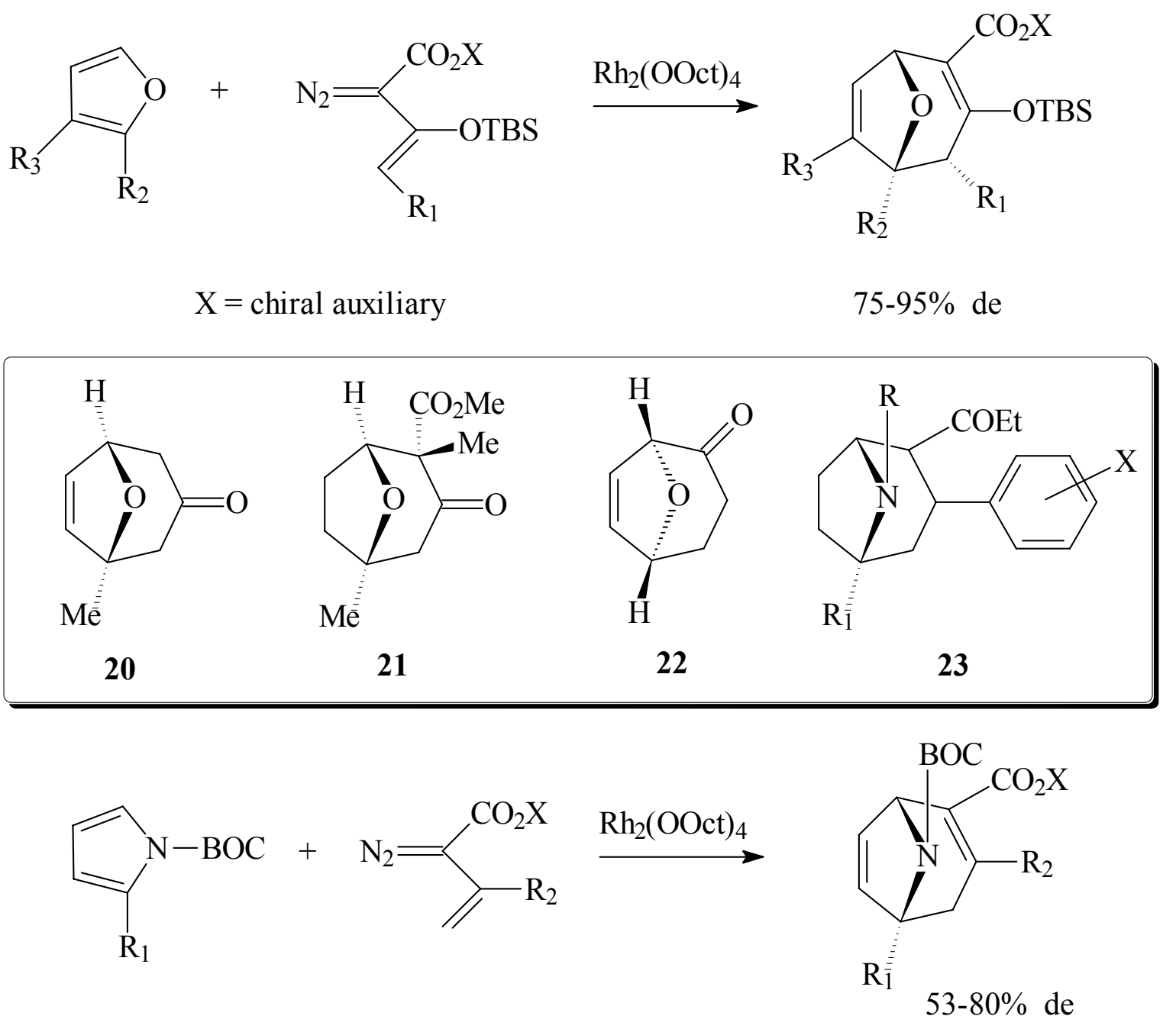

Scheme 4. Diastereoselective synthesis of oxabicyclooctanones and tropanes

Enantioselective approaches have surveyed two distinct types of homochiral dirhodium(II) carboxylates. Brünner et al (1989) used carboxylate ligands of the type $\mathrm{R}^{1} \mathrm{R}^{2} \mathrm{R}^{3} \mathrm{CCOO}$, as in catalysts 6 (substituents varied from $\mathrm{H}, \mathrm{Me}$, and $\mathrm{Ph}$; to $\mathrm{OH}, \mathrm{NHAc}$, and $\mathrm{CF}_{3}$ ) and Kennedy et al (1990) persued the chiral prolinate derivatives $7(\mathrm{Z}=\mathrm{H})$. They found that enantioselectivities in the cyclopropanation of styrene with ethyl diazoacetate were less than $12 \%$ ee and $30 \%$ ee respectively. More recently, Davies et al $(1993 \mathrm{~b}, 1996 \mathrm{~b}, 1997)$ have used modified prolinate catalysts with vinyldiazoacetates to achieve enantioselectivities of $\geq 90 \%$, with correspondingly high diastereoselectivities (Table 2). It has further been shown that with suitably fuctionalised vinyldiazoacetates, the cyclopropyl products can afford cyclopentenes with high stereoselectivity (Davies et al, 1998b). A recent catalyst, based on an axially 
Table 2. Dirhodium(II) prolinate catalyzed intermolecular cyclopropanation with vinyldiazoacetates<smiles></smiles>

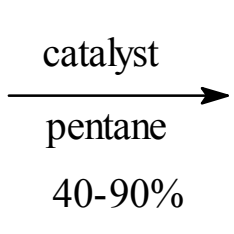<smiles>[R]C1CC1(/C=C/c1ccccc1)C(C)=O</smiles>

\begin{tabular}{|c|c|c|}
\hline $\mathbf{R}$ & $\begin{array}{r}\text { ee, \% with } \\
\mathbf{R h}_{\mathbf{2}} \mathbf{( T B S P}_{\mathbf{4}}\end{array}$ & $\begin{array}{c}\text { ee, \% with } \\
\mathbf{R h}_{\mathbf{2}} \text { (DOSP) }\end{array}$ \\
\hline $\mathrm{Ph}$ & 90 & 98 \\
$\mathrm{pClC}_{6} \mathrm{H}_{4}$ & 89 & $>97$ \\
$\mathrm{pMeOC}_{6} \mathrm{H}_{4}$ & 83 & 90 \\
$\mathrm{AcO}$ & 76 & 95 \\
$\mathrm{EtO}$ & 59 & 93 \\
$\mathrm{nBu}$ & $>90$ & - \\
$\mathrm{Et}$ & $>95$ & - \\
$\mathrm{iPr}$ & 95 & - \\
\hline
\end{tabular}

dissymmetric biphenyl, does as yet not appear to offer any significant advantages over existing examples (Ishitani and Achiwa, 1997).

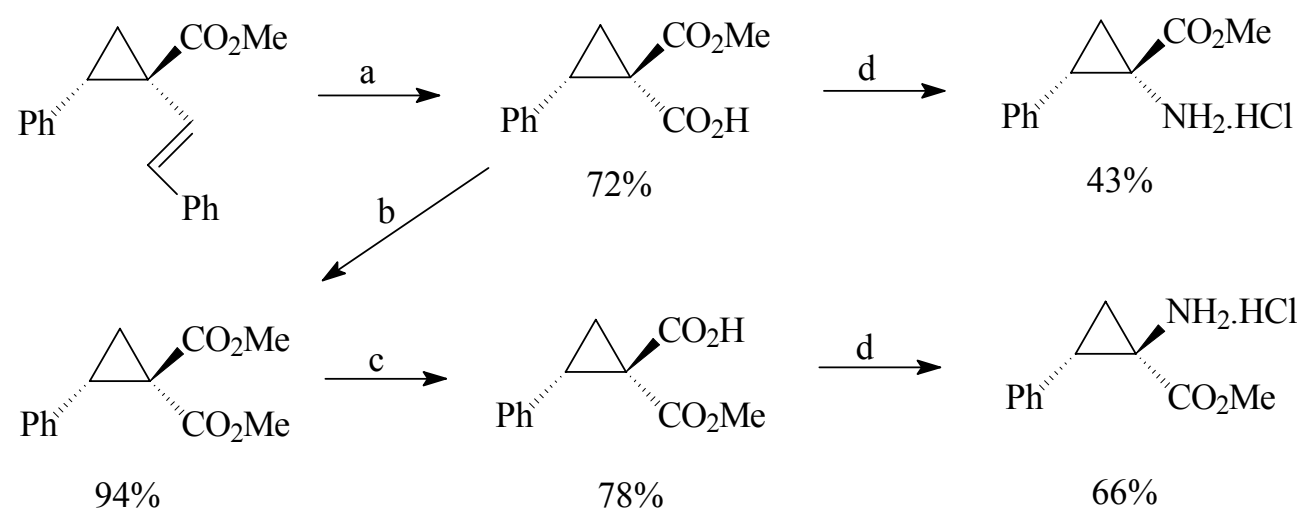

a: $\mathrm{RuCl}_{3} / \mathrm{NaIO}_{4}$ b: $\mathrm{K}_{2} \mathrm{CO}_{3}, \mathrm{Me}_{2} \mathrm{SO}_{4}$ c: $\mathrm{LiOH}, \mathrm{MeOH}$ d: $\mathrm{NEt}_{3}$, DPPA, tBuOH; $\left[\left(\mathrm{CH}_{3}\right)_{3} \mathrm{COCO}\right]_{2} \mathrm{O} ; \mathrm{NaOH} / \mathrm{H}_{2} \mathrm{O} / \mathrm{THF} ; \mathrm{HCl} / \mathrm{EtOAc}$

Scheme 5. Stereoselective synthesis of cyclopropaneamino acids 


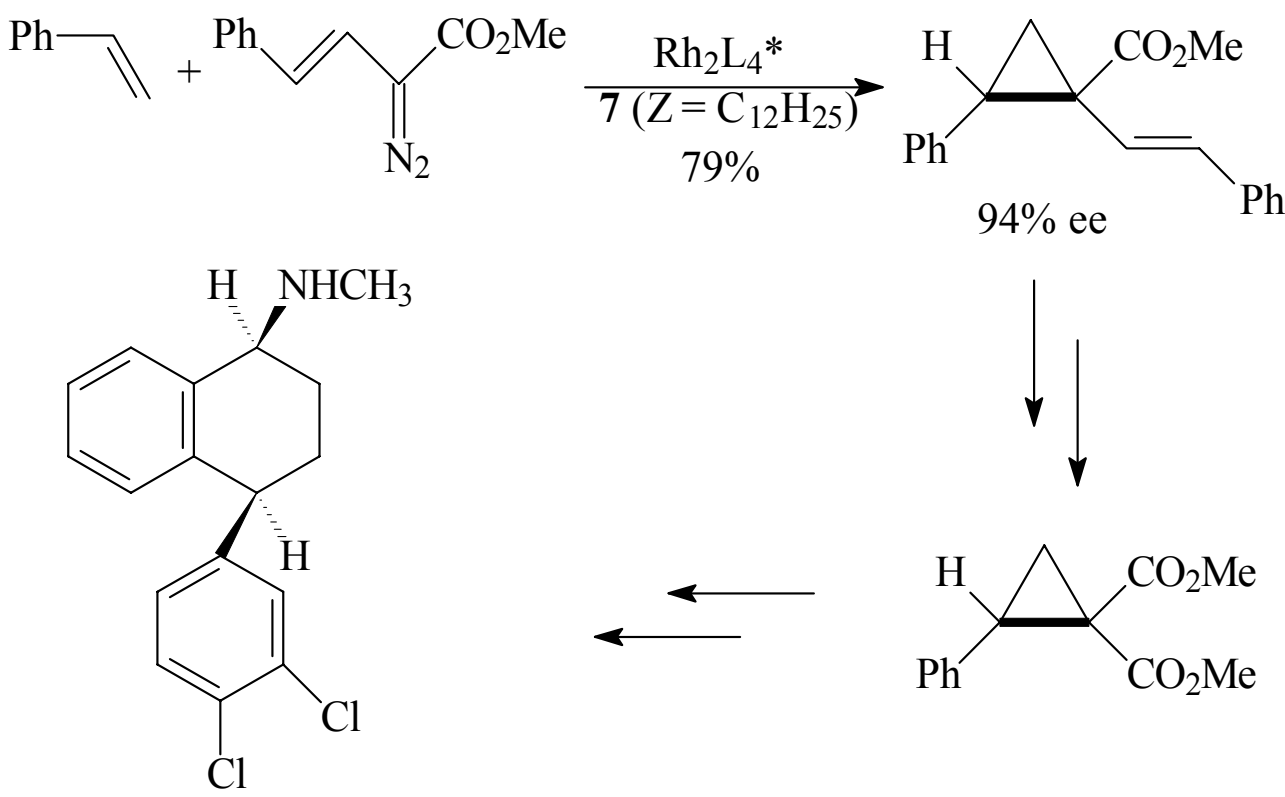

\section{Sertraline}

Scheme 6. Enantioselective synthesis of the antidepressant Sertraline

The vinyl functionality that exists in the cyclopropane offers a number of opportunities for further transformations. One generally useful application is for the stereoselective synthesis of cyclopropaneamino acids (Scheme 5) (Davies et al, 1993b, 1996b). This approach has been utilised in a recent synthesis of the antidepressant sertraline (Scheme 6) (Corey and Grant, 1994).

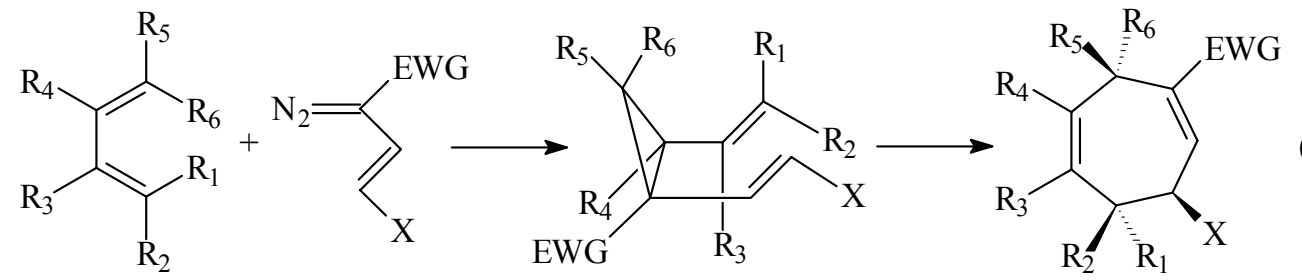

EWG $=$ electron-withdrawing group

The extension of asymmetric vinylcarbenoid cyclopropanation to dienes affords a good general entry into seven-membered rings equation 2 (Davies et al, 1994b). The stereoselectivity that occurs results in a strong preference for the formation of cis-divinylcyclopropanes, and the subsequent Cope rearrangement follows with a predictable stereochemical outcome. 


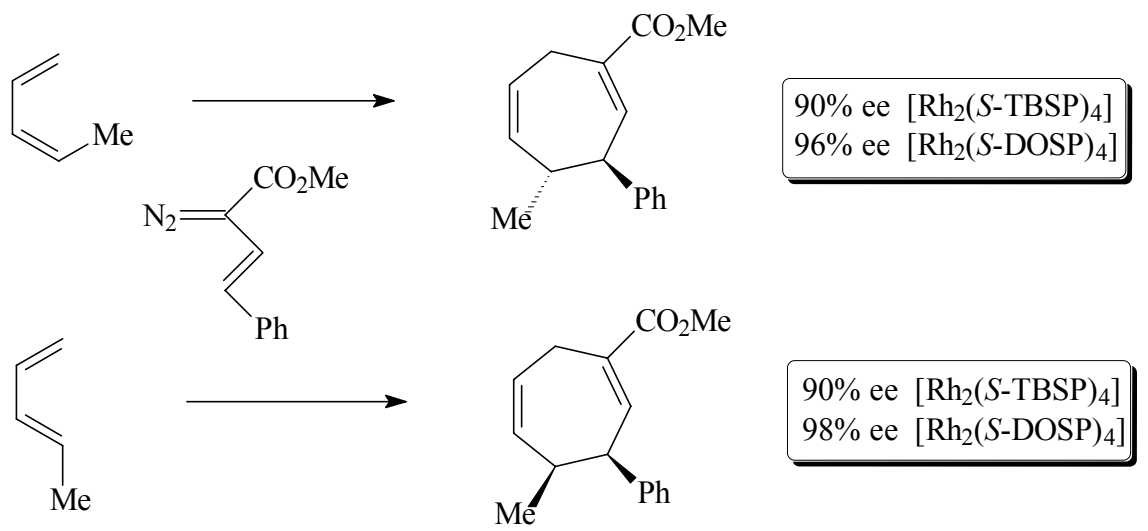

Scheme 7. Enantioselective cycloheptatriene synthesis

This methodology, which represents a formal [3 + 4]-cycloaddition, has been well exploited by Davies et al (1994b) (Scheme 7) (Table 3).

Table 3. Enantioselective synthesis of bicyclo[3.2.1] octadienes

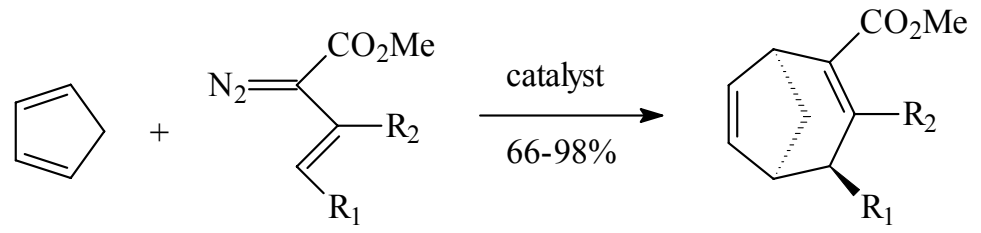

\begin{tabular}{|c|c|c|c|}
\hline $\mathbf{R}_{\mathbf{1}}$ & $\mathbf{R}_{\mathbf{2}}$ & $\begin{array}{c}\text { ee \% with } \\
\mathbf{R h}_{\mathbf{2}}(\boldsymbol{S} \text {-TBSP })_{\mathbf{4}}\end{array}$ & $\begin{array}{c}\text { ee \% with } \\
\mathbf{R h}_{\mathbf{2}}(\boldsymbol{S} \text {-DOSP })_{\mathbf{4}}\end{array}$ \\
\hline $\mathbf{P h}$ & $\mathrm{H}$ & 75 & 93 \\
$\mathrm{Me}$ & $\mathrm{H}$ & 83 & 92 \\
$\mathrm{CH}=\mathrm{CH}_{2}$ & $\mathrm{H}$ & 91 & 93 \\
$\mathrm{H}$ & $\mathrm{H}$ & 63 & - \\
$\mathrm{CO}_{2} \mathrm{Et}$ & $\mathrm{H}$ & 10 & - \\
$\mathrm{H}$ & $\mathrm{Me}$ & 64 & - \\
$\mathrm{H}$ & OTBS & 42 & - \\
\hline
\end{tabular}

Although the dirhodium(II) carboxamidate catalysts 9-12 are able to provide substituted cyclopropanes with reasonable levels of enantioselectivity, they suffer the drawback of poor 
diastereoselective when diazoacetates are employed, with mixtures of trans- and cis-adducts being formed (Table 4) (Doyle et al, 1993d; Müller et al, 1995; Watanabe et al, 1996b). Diastereoselectivity can only be effectively induced when sterically demanding diazo esters can be employed. The most noteworthy recent examples have been reported with the catalysts $\mathrm{Rh}_{2}(4 S \text {-IBAZ) })_{4} \mathbf{1 2 b}$ (Doyle et al, 1996d) and $\mathrm{Rh}_{2}(S \text {-PTPI })_{4}$ (Kitagaki et al, 1997) where enantioselectivities of up to $95 \%$ have been achieved in selected systems. The situation has been somewhat improved by the discovery that methyl phenyldiazoacetate $\mathbf{2 4}$ is an excellent substrate for intermolecular cyclopropanation (Table 5) (Davies et al, 1996d; Doyle et al, 1996b).

Homochiral dirhodium(II) carboxamidates, in particular 9a, have proven to be exceptional catalysts for highly enantioselective intermolecular cyclopropenation (Table 6) (Doyle et al, 1994d). Since the cyclopropene products can be quantitatively reduced to $c i s$-cyclopropanes, this provides an alternative route to these products in high enantiomeric purity.

Table 4. Dirhodium(II) carboxamidate catalyzed intermolecular cyclopropanation

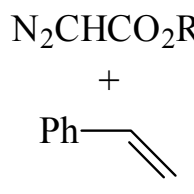

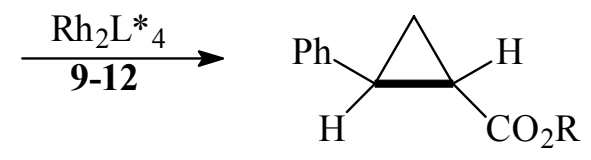

Trans

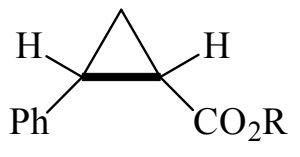

Cis

\begin{tabular}{|c|c|c|c|}
\hline R & Catalyst & $\begin{array}{c}\text { Trans yield \% } \\
\text { (de \%) }\end{array}$ & $\begin{array}{c}\text { Cis yield \% } \\
\text { (de \%) }\end{array}$ \\
\hline$d$-menthyl & $\mathrm{Rh}_{2}(5 S \text {-MEPY })_{4}$ & $57(31)$ & $43(88)$ \\
Et & $\mathrm{Rh}_{2}(5 S \text {-MEPY })_{4}$ & $56(58)$ & $44(33)$ \\
$l$-menthyl & $\mathrm{Rh}_{2}(4 S \text {-PHOX })_{4}$ & $27(40)$ & $73(72)$ \\
Et & $\mathrm{Rh}_{2}(4 S \text {-PHOX })_{4}$ & $34(24)$ & $66(57)$ \\
$d$-menthyl & $\mathrm{Rh}_{2}(4 R \text {-BNOX })_{4}$ & $67(34)$ & $33(62)$ \\
Et & $\mathrm{Rh}_{2}(4 R \text {-BNOX })_{4}$ & $46(8)$ & $54(13)$ \\
cyc- $\left(\mathrm{C}_{6} \mathrm{H}_{11}\right)_{2} \mathrm{CH}$ & $\mathrm{Rh}_{2}(4 S \text {-IBAZ })_{4}$ & $34(77)$ & $66(95)$ \\
Et & $\mathrm{Rh}_{2}(4 S \text {-IBAZ })_{4}$ & $36(47)$ & $64(73)$ \\
Et & $\mathrm{Rh}_{2}(4 S \text {-MACIM })_{4}$ & $43(30)$ & $57(37)$ \\
\hline
\end{tabular}

\subsection{Intramolecular Processes}

Because of geometric constraints, intramolecular cyclopropanations of unsaturated diazocarbonyl compounds can produce only one fused bicyclic cyclopropane (the cis isomer). Tanimori et al (1997) have reported a chiral auxiliary approach to intramolecular cyclopropanation of a diazoacetate in their synthetic route to the carbocyclic moiety of the anti-HIV agent carbovir equation 3 . This is, however, a rare diastereoselective approach, since the dirhodium(II) carboxamidate catalysts 9-12 have proven to be 
most efficient and selective for reactions of diazoacetates and diazoacetamides (Doyle et al, 1995c, 1997c, 1998d).

Table 5. Enantioselective intermolecular cyclopropanation with phenyldiazoacetate<smiles>[R]C([R])=C</smiles><smiles>[R]C1([R2])C[C@@]1(CCCCCCCC)c1ccccc1</smiles>

24

\begin{tabular}{|c|c|c|c|}
\hline $\mathbf{R}_{\mathbf{1}}$ & $\mathbf{R}_{\mathbf{2}}$ & Catalyst & ee of $\boldsymbol{Z}, \boldsymbol{\%}$ \\
\hline $\mathrm{Ph}$ & $\mathrm{H}$ & $\mathrm{Rh}_{2}(S \text {-TBSP })_{4}$ & 87 \\
$\mathrm{pClC}_{6} \mathrm{H}_{4}$ & $\mathrm{H}$ & $\mathrm{Rh}_{2}(S \text {-TBSP })_{4}$ & 85 \\
$\mathrm{pMePC}_{6} \mathrm{H}_{4}$ & $\mathrm{H}$ & $\mathrm{Rh}_{2}(S-\mathrm{TBSP})_{4}$ & 88 \\
$\mathrm{EtO}$ & $\mathrm{H}$ & $\mathrm{Rh}_{2}(S-\mathrm{DOSP})_{4}$ & 66 \\
$\mathrm{nBuO}$ & $\mathrm{H}$ & $\mathrm{Rh}_{2}(S \text {-DOSP })_{4}$ & 64 \\
$\mathrm{nBu}$ & $\mathrm{H}$ & $\mathrm{Rh}_{2}(S-\mathrm{DOSP})_{4}$ & 77 \\
$\mathrm{Ph}$ & $\mathrm{Ph}$ & $\mathrm{Rh}_{2}(S-\mathrm{TBSP})_{4}$ & 97 \\
$\mathrm{Ph}$ & $\mathrm{Me}$ & $\mathrm{Rh}_{2}(S-\mathrm{TBSP})_{4}$ & $85(E), 81(Z)$ \\
\hline
\end{tabular}

Table 6. Enantioselective intermolecular cyclopropenation
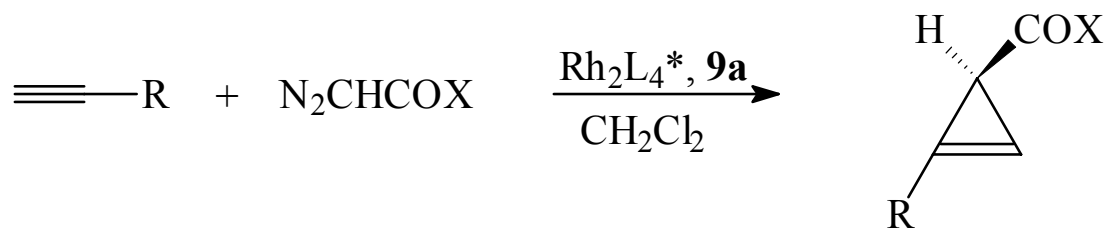

\begin{tabular}{|c|c|c|c|}
\hline $\mathbf{R}$ & $\mathbf{X}$ & Yield \% & ee \% \\
\hline $\mathrm{CH}(\mathrm{OEt})_{2}$ & $\mathrm{OMe}$ & 42 & $\geq 98$ \\
$\mathrm{CH}_{2} \mathrm{OMe}$ & $\mathrm{O}^{\mathrm{t}} \mathrm{Bu}$ & 52 & 78 \\
$\mathrm{CH}_{2} \mathrm{OMe}$ & $\mathrm{OEt}$ & 73 & 69 \\
${ }^{\mathrm{t}} \mathrm{Bu}$ & $\mathrm{OEt}$ & 85 & 57 \\
$\mathrm{CH}_{2} \mathrm{OMe}$ & $\mathrm{NMe}_{2}$ & 22 & $\geq 94$ \\
${ }^{\mathrm{t}} \mathrm{Bu}$ & $\mathrm{NMe}_{2}$ & 47 & 89 \\
\hline
\end{tabular}


<smiles>[R20]C(=O)C(=[W])C(=O)CCC=C</smiles>

$\mathrm{R}^{*}=(R)$-pantolactone carbovir<smiles>[R]C([R])=CN[Z](=O)C(N)=O</smiles>

25: $\begin{aligned} n & =1,2 \\ \mathrm{Z} & =\mathrm{O}, N-t \mathrm{Bu}\end{aligned}$<smiles>[R]C1([R])[CH][C@@H]2[Z](=O)[CH][C@@H]21</smiles>

26: $n=1,2$ $\mathrm{Z}=\mathrm{O}, N-t \mathrm{Bu}$

Excellent enantioselectivities have been reported in a series of allylic diazoacetates $\mathbf{2 5}(\mathrm{n}=1, \mathrm{Z}=\mathrm{O})$ catalysed by $\mathrm{Rh}_{2}(5 S \text {-MEPY })_{4}\left(S\right.$-9a), and $\mathrm{Rh}_{2}(5 R \text {-MEPY })_{4}(R-\mathbf{9 a})$ to give fused cyclopropyl lactones 26 $(\mathrm{n}=1, \mathrm{Z}=\mathrm{O})$ equation 4 (Doyle et al, 1991b, 1995c, 1996e). Cyclopropanation of homoallylic diazoesters $25(\mathrm{n}=2, \mathrm{Z}=\mathrm{O})$ (Martin et al, 1992a) and $N$-tert-butyldiazoacetamides $25\left(\mathrm{n}=2, \mathrm{Z}=N-{ }^{t} \mathrm{Bu}\right)$ equation 4 (Doyle et al, 1994e) proceeded with moderate to high enantioselectivities with the same catalysts.

It has further been shown that enantioselectivities obtained in the catalysed cyclopropanation of allylic diazoacetates 27a-g to give the cyclopropyl $\gamma$-lactones 28a-g, were largely dependant on the position of vinylic substitution (Table 7) (Doyle et al, 1995c). As is shown in Table 7, careful selection of the catalyst becomes necessary in order to optimise the enantioselectivity (Doyle et al, 1995d, 1997c). Application of the enantiomeric catalysts to the cyclopropanation of these allylic diazoacetates provide the cyclopropyl lactone products with the same enantiomeric excesses, but with the opposite absolute configurations. A recent contribution to the area by Martin and Hillier (1998) has investigated the complimentarity of chiral diazoacetates and chiral catalysts in a form of double diastereodifferentioncyclopropanation.

Several pharmacologically important molecules have been synthesized through the use of the above methodology, using either of the enantiomeric catalysts 9a. As outlined in Scheme 8, Martin et al (1992b, 1993) synthesized trisubstituted cyclopropanes as conformationally restricted peptide isosteres for renin 29 and collagenase inhibitors, and Rogers et al (1995) have synthesizes presqualene alcohol 30. In addition, the products of these cyclopropanation reactions may serve as synthetic precursors to cischrysanthemic acid (Mukaiyama et al, 1983) and the pheromone $R$-(-)-dictyopterene C (Schotten et al, 1986).

With homoallylic diazoacetates $31\left(\mathrm{n}=2, \mathrm{R}^{4}=\mathrm{H}\right)$ (Martin et al, 1992a; Doyle et al, 1995c) and allylic diazopropionates $31\left(n=1, R^{4}=M e\right)$ (Doyle and Zhou, 1995e), there is a moderate reduction in the enantioselectivity with a similar selection of dirhodium catalysts (Table 8). 
Table 7. Enantioselective intramolecular cyclopropanation of allylic diazoacetates<smiles>[R]C([R])=C([R])COC(=O)CN</smiles>

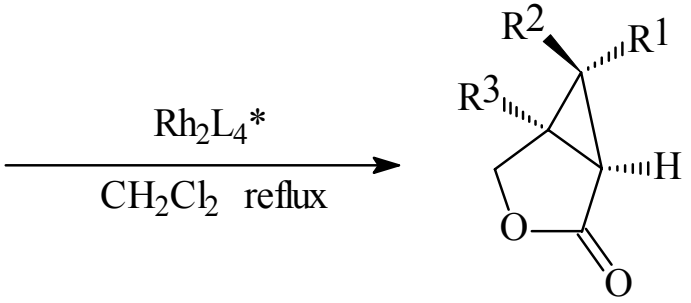

$27 \mathbf{a}-\mathbf{g}$

28a-g

\begin{tabular}{|c|c|c|c|c|c|c|}
\hline $\mathbf{2 7}$ & $\mathbf{R}^{\mathbf{1}}$ & $\mathbf{R}^{2}$ & $\mathbf{R}^{\mathbf{3}}$ & Catalyst & Yield \% (ee \%) & Config. \\
\hline $\mathbf{a}$ & $\mathrm{H}$ & $\mathrm{H}$ & $\mathrm{H}$ & $\mathbf{9 a}$ & $75(95)$ & $(1 R, 5 S)$ \\
$\mathbf{b}$ & $\mathrm{Me}$ & $\mathrm{Me}$ & $\mathrm{H}$ & $\mathbf{9 a}$ & $89(98)$ & $(1 S, 5 R)$ \\
$\mathbf{c}$ & $\mathrm{H}$ & $\mathrm{H}$ & $\mathrm{Me}$ & $\mathbf{9 a}$ & $72(7)$ & $(1 R, 5 S)$ \\
$\mathbf{c}$ & $\mathrm{H}$ & $\mathrm{H}$ & $\mathrm{Me}$ & $\mathbf{1 1 d}$ & $75(89)$ & $(1 S, 5 R)$ \\
$\mathbf{d}$ & $\mathrm{H}$ & $\mathrm{Ph}$ & $\mathrm{H}$ & $\mathbf{9 a}$ & $70(\geq 94)$ & $(1 R, 5 S)$ \\
$\mathbf{e}$ & $\mathrm{Ph}$ & $\mathrm{H}$ & $\mathrm{H}$ & $\mathbf{9 a}$ & $78(68)$ & $(1 R, 5 S)$ \\
$\mathbf{e}$ & $\mathrm{Ph}$ & $\mathrm{H}$ & $\mathrm{H}$ & $\mathbf{1 1 d}$ & $61(96)$ & $(1 R, 5 S)$ \\
$\mathbf{f}$ & $\mathrm{Pr}$ & $\mathrm{H}$ & $\mathrm{H}$ & $\mathbf{9 a}$ & $93(85)$ & $(1 R, 5 S)$ \\
$\mathbf{f}$ & $\mathrm{Pr}$ & $\mathrm{H}$ & $\mathrm{H}$ & $\mathbf{1 1 d}$ & $83(95)$ & $(1 R, 5 S)$ \\
$\mathbf{g}$ & $\mathrm{H}$ & $i \mathrm{Pr}$ & $\mathrm{H}$ & $\mathbf{9 a}$ & $85(\geq 94)$ & $(1 R, 5 S)$ \\
\hline
\end{tabular}

Analogous intramolecular cyclopropanation of $N$-allyl diazoacetamides $32(\mathrm{n}=1)$ (Doyle et al, 1995c, 1996f) and $N$-tert-butyl- $N$-homoallylic diazoacetamides $32(\mathrm{n}=2)$ (Doyle et al, 1994e) to give the cyclopropyl lactams have progressively been refined to high yielding, highly enantioselective processes (Table 9).
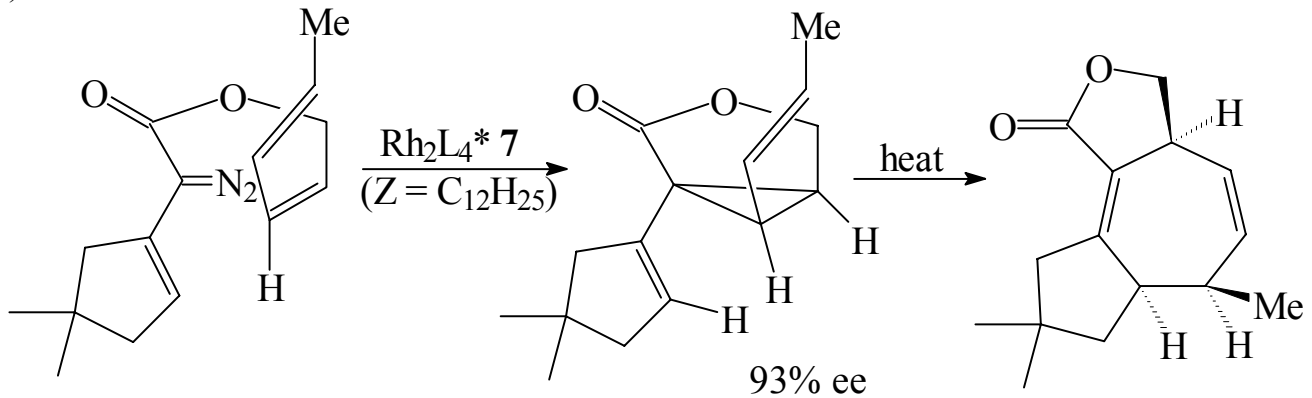

Although diazoacetates and diazoacetamides generally undergo dirhodium(II)-catalysed intramolecular cyclopropanation with high enantiocontrol, the same is not true for diazoketones. Here the best results were obtained from copper-based catalysts (Doyle et al, 1997d).

The Davies group has demonstrated the applicability of their formal [3+4]-cycloaddition in an intramolecular example as part of a synthesis of 5-epitremulenolide equation 5 (Davies and Doan, 1996e). 
Outside of two very recent preliminary reports from the Doyle group (Doyle et al, 1999b, 1999c), no widespread success with intramolecular cyclopropenation has been developed. These reactions often produce unstable fused cyclopropenes that undergo ring opening to vinylcarbenes that can react by a number of pathways, often giving rise to multiple products (Padwa et al, 1991, 1993).<smiles>[R]C([R])=CCOC(=O)C#N</smiles><smiles>CC(C)=CCC/C(C)=C/CC/C(C)=C/COC(=O)C=N</smiles>

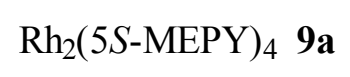

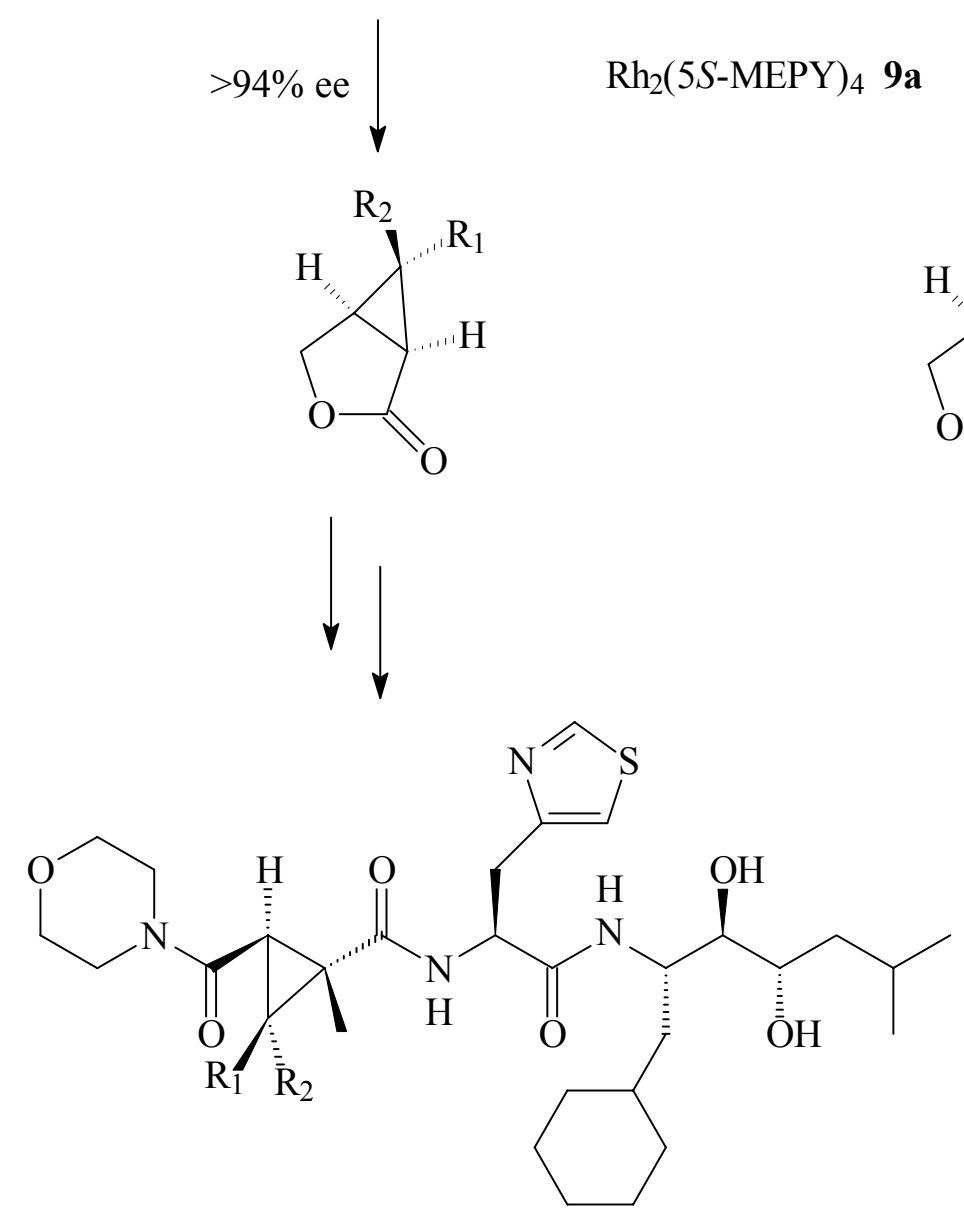

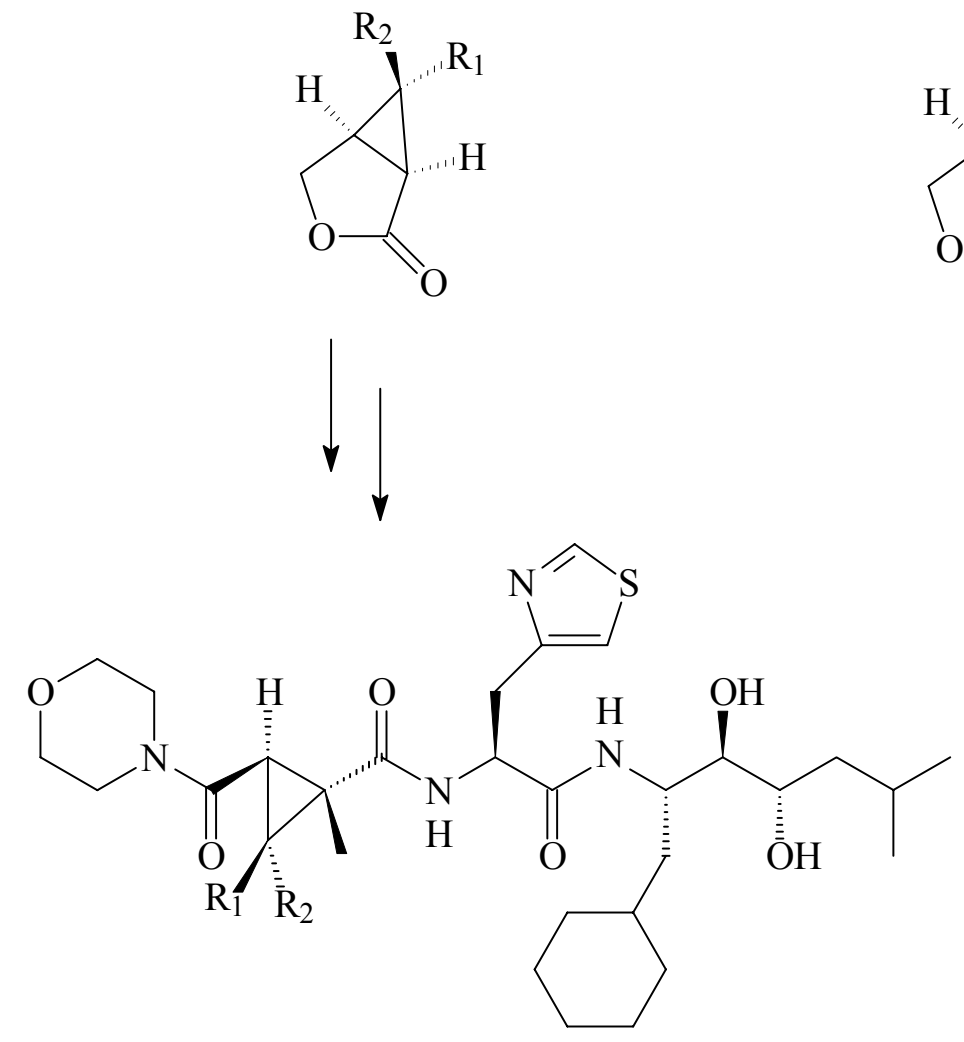

29 renin inhibitor<smiles>CC(C)=CCC/C(C)=C/CC[C@]1(C)[C@H]2COC(=O)[C@H]21</smiles><smiles>C[V][V]</smiles><smiles>CC(C)=CCCC(C)=CCCC(C)=CC1C(CO)C1(C)CCC=C(C)CCC=C(C)C</smiles>

30 presqualene alcohol

Scheme 8. Applications of enantioselective intramolecular cyclopropanation 
Table 8. Enantioselective intramolecular cyclopropanation of homoallylic diazoacetates and allylic diazopropionates<smiles>[R]C(=N)C(=O)OCC([R])=C([R])[R]</smiles>

31

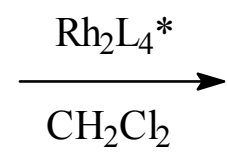<smiles>[R4]C1([R4])[C@@]2([R4])COC(=O)[C@]12[R4]</smiles>

\begin{tabular}{|c|c|c|c|c|c|c|}
\hline $\mathbf{n}$ & $\mathbf{R}^{1}$ & $\mathbf{R}^{2}$ & $\mathbf{R}^{3}$ & $\mathbf{R}^{4}$ & Cat. & Yield \% (ee \%) \\
\hline 2 & $\mathrm{H}$ & $\mathrm{H}$ & $\mathrm{H}$ & $\mathrm{H}$ & $\mathbf{9 a}$ & $80(71)$ \\
2 & $\mathrm{Me}$ & $\mathrm{Me}$ & $\mathrm{H}$ & $\mathrm{H}$ & $\mathbf{9 a}$ & $74(77)$ \\
2 & $\mathrm{H}$ & $\mathrm{Ph}$ & $\mathrm{H}$ & $\mathrm{H}$ & $\mathbf{9 a}$ & $73(88)$ \\
2 & $\mathrm{Ph}$ & $\mathrm{H}$ & $\mathrm{H}$ & $\mathrm{H}$ & $\mathbf{9 a}$ & $55(73)$ \\
2 & $\mathrm{H}$ & $\mathrm{Et}$ & $\mathrm{H}$ & $\mathrm{H}$ & $\mathbf{9 a}$ & $80(90)$ \\
2 & $\mathrm{H}$ & $\mathrm{H}$ & $\mathrm{Me}$ & $\mathrm{H}$ & $\mathbf{9 a}$ & $76(83)$ \\
1 & $\mathrm{Me}$ & $\mathrm{Me}$ & $\mathrm{H}$ & $\mathrm{Me}$ & $\mathbf{1 0 a}$ & $81(71)$ \\
1 & $\mathrm{H}$ & $n \mathrm{Pr}$ & $\mathrm{H}$ & $\mathrm{Me}$ & $\mathbf{1 0 a}$ & $62(85)$ \\
1 & $\mathrm{H}$ & $\mathrm{Ph}$ & $\mathrm{H}$ & $\mathrm{Me}$ & $\mathbf{1 0 a}$ & $65(78)$ \\
\hline
\end{tabular}

\subsection{Insertion Products}

Catalytically generated metal carbenes have been shown to be capable of highly versatile insertion into carbon-hydrogen and heteroatom-hydrogen bonds equation 6.

$$
\mathrm{X}-\mathrm{H}+\mathrm{L}_{\mathrm{n}} \mathrm{M}=\mathrm{CR}_{2} \longrightarrow \mathrm{R}_{2} \mathrm{C}^{\prime}{ }_{\mathrm{X}}^{\mathrm{H}}+\mathrm{ML}_{\mathrm{n}}
$$

Although generally indiscriminate, the advent of dirhodium(II) catalysts provided the required element of control to make these highly attractive C-C bond-forming processes (Maas, 1987; Doyle, 1986, 1995a; Ye and McKervey, 1994; Nefedov et al, 1992; Padwa and Krumpe, 1992). Although the 
mechanism of the transition metal catalysed C-H insertion reactions has been the subject of considerable speculation (Taber, 1991; Doyle, 1992), there is general agreement that insertion occurs through a metal carbene intermediate. Doyle and co-workers have suggested the mechanism depicted below as a suitable model for the C-H insertion process (Scheme 9) (Doyle et al, 1993b).

Table 9. Enantioselective intramolecular cyclopropanation of $N$-allyl and $N$-homoallylic diazoacetamides<smiles>[R]C([R])=C([R])CNC(=O)C=N</smiles><smiles>[R12][14CH](C)[14CH2][4H]</smiles><smiles>[R4]C1C2C(=O)NCC2([R2])C1([R2])[R]</smiles>

32

\begin{tabular}{|c|c|c|c|c|c|c|}
\hline $\mathbf{n}$ & $\mathbf{R}^{\mathbf{1}}$ & $\mathbf{R}^{\mathbf{2}}$ & $\mathbf{R}^{\mathbf{3}}$ & $\mathbf{R}^{\mathbf{4}}$ & $\mathbf{C a t}$ & Yield \% (ee \%) \\
\hline 1 & $\mathrm{H}$ & $\mathrm{H}$ & $\mathrm{H}$ & $\mathrm{H}$ & $\mathbf{1 0 a}$ & $40(98)$ \\
1 & $\mathrm{Me}$ & $\mathrm{Me}$ & $\mathrm{H}$ & $\mathrm{Me}$ & $\mathbf{1 0 a}$ & $91(94)$ \\
1 & $\mathrm{H}$ & $\mathrm{Pr}$ & $\mathrm{H}$ & $\mathrm{Me}$ & $\mathbf{1 1 d}$ & $88(95)$ \\
1 & $\mathrm{Pr}$ & $\mathrm{H}$ & $\mathrm{H}$ & $\mathrm{Me}$ & $\mathbf{1 1 d}$ & $93(92)$ \\
1 & $\mathrm{H}$ & $\mathrm{H}$ & $\mathrm{Me}$ & $\mathrm{Me}$ & $\mathbf{1 1 d}$ & $84(44)$ \\
2 & $\mathrm{H}$ & $\mathrm{H}$ & $\mathrm{H}$ & $t \mathrm{Bu}$ & $\mathbf{9 a}$ & $60(60)$ \\
2 & $\mathrm{Me}$ & $\mathrm{Me}$ & $\mathrm{H}$ & $t \mathrm{Bu}$ & $\mathbf{9 a}$ & $75(75)$ \\
2 & $\mathrm{H}$ & $\mathrm{Et}$ & $\mathrm{H}$ & $t \mathrm{Bu}$ & $\mathbf{9 a}$ & $94(90)$ \\
2 & $\mathrm{Et}$ & $\mathrm{H}$ & $\mathrm{H}$ & $t \mathrm{Bu}$ & $\mathbf{9 a}$ & $62(67)$ \\
2 & $\mathrm{H}$ & $\mathrm{H}$ & $\mathrm{Me}$ & $t \mathrm{Bu}$ & $\mathbf{9 a}$ & $87(78)$ \\
\hline
\end{tabular}

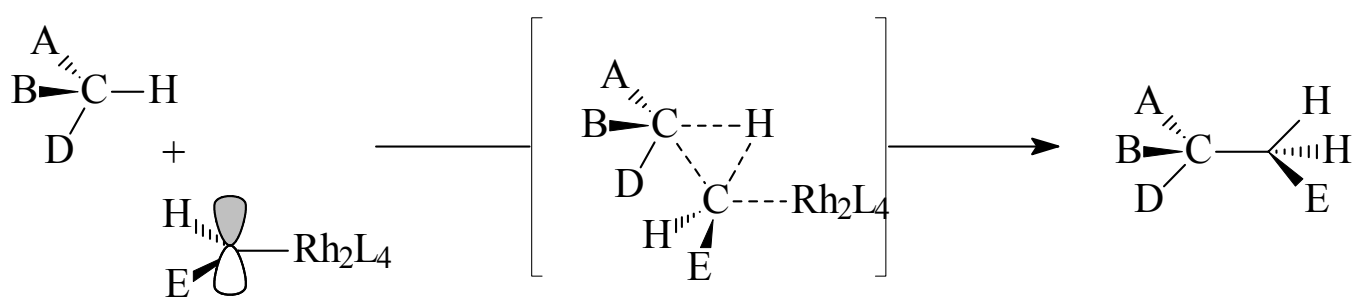

Scheme 9. Proposed mechanism of C-H insertion 


\subsubsection{Carbon-Hydrogen Insertion Products}

Although examples of dirhodium(II) catalysed intermolecular C-H insertion reactions are known, they generally lead to multiple products and require highly electrophilic catalysts in order to minimise competitive reactions such as formal carbene dimer formation. The yields and regioselectivities of these reactions are highly dependant on the catalyst employed (Demonceau et al, 1981, 1984).

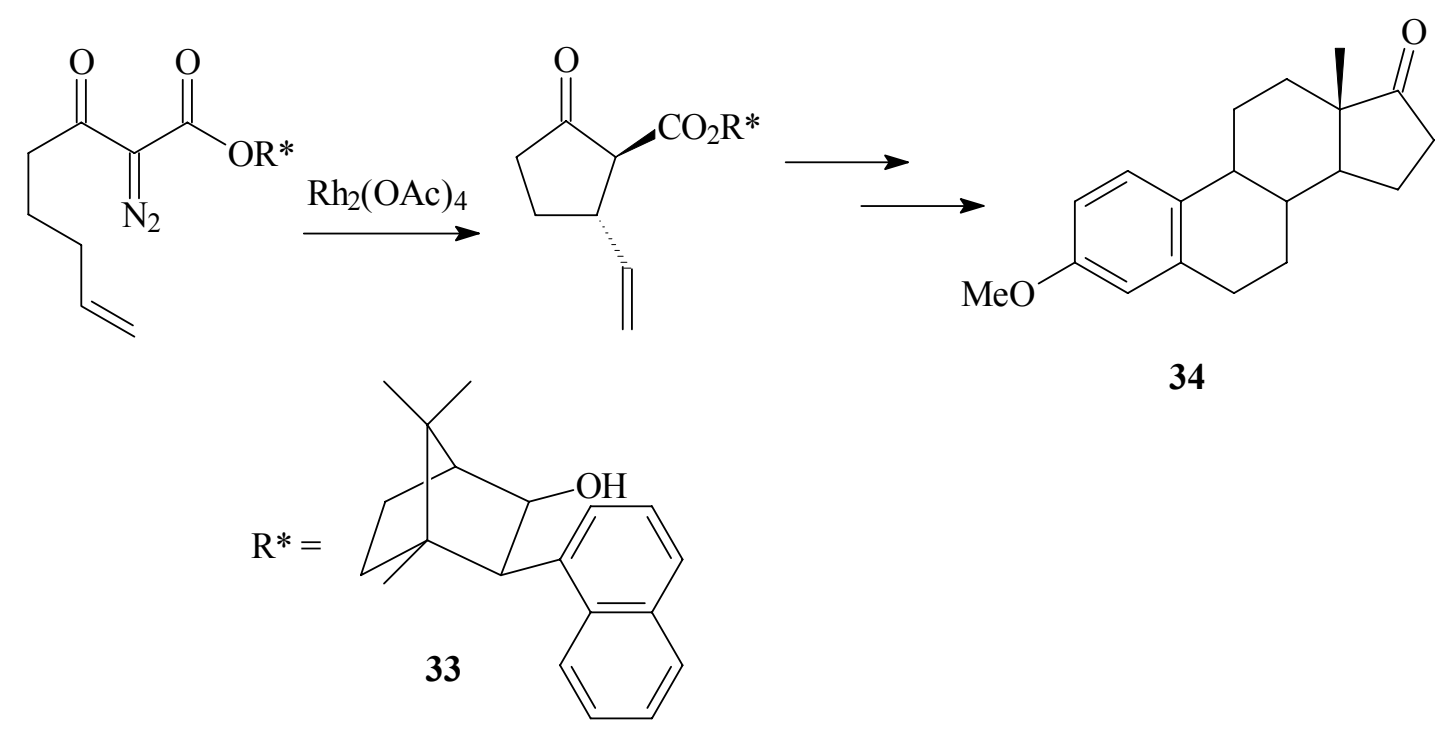

Scheme 10. Diastereoselective route to (+)-estrone methyl ether

Intramolecular C-H insertion reactions of diazocarbonyl compounds are more effective and selective, and they have become synthetically relevant, with the dirhodium(II) carboxylates and carboxamidates 7-12 as the catalysts of choice (Doyle 1994a, Watanabe et al, 1995; Doyle and McKervey, 1997a, Anada and Hashimoto, 1998a). Two diastereoselective approaches are worthy of note. Both groups have used 1-naphthylborneol $\mathbf{3 3}$ esters as the chiral auxiliary for asymmetric induction in CH insertion reactions (Taber et al, 1987, 1998; Wee and Liu, 1996). Taber and co-workers achieved diastereoselectivities of 83:17-92:8, which corresponds to enantiomeric excesses for the hydrolysed ester of 66 to $84 \%$.

This procedure was extended to a synthesis of (+)-estrone methyl ether 34 (Scheme 10). Wee and Liu (1996) used this auxiliary in the C-H insertion reactions of diazomalonamides equation 7.

Enantioselective adaptations have been a more recent development. The McKervey group (McKervey an Ye, 1992; Kennedy et al, 1990; Doyle and McKervey, 1997a) and others (Hashimoto et al, 1990, 1994; Anada and Hashimoto, 1998a, 1998b) have utilised dirhodium(II) carboxylates derived from $\mathrm{N}$-protected amino acids (catalysts $\mathbf{7}$ and $\mathbf{8}$ respectively) to catalyse the enantioselective $\mathrm{C}-\mathrm{H}$ insertion of diazoketone derivatives. Enantioselectivities in the $\mathrm{C}-\mathrm{H}$ insertion reactions of $\alpha$-diazo- $\beta$-ketosulphones catalysed by $7(\mathrm{Z}=\mathrm{H})$ were low $(\sim 12 \%$ ee), although yields were high Kennedy et al, 1990). With a series of methyl diazo ketones 35 , the same catalyst yielded the corresponding chromanones with enantioselectivities (for the major cis isomers) of 62-82\% ee equation 8 (McKervey an Ye, 1992). Taber and co-workers have very recently published a preliminary report on the preparation of a new type of chiral catalyst $\mathbf{3 6}$ (enantiomeric $\mathbf{M}$ and $\mathbf{P}$ ) that has backbone chirality. Whilst this design strategy may 
have potential, the initial intramolecular $\mathrm{C}-\mathrm{H}$ insertions with a diazoketone only afforded an enantioselectivity of $36 \%$ (Taber et al, 1999).<smiles></smiles>

$$
\begin{aligned}
& \mathrm{PMP}=p \mathrm{MeOC}_{6} \mathrm{H}_{4} \\
& \mathrm{R}^{*}=\mathbf{3 3}
\end{aligned}
$$

$$
\begin{aligned}
& \mathrm{R}=n \mathrm{Hex} \\
& \mathrm{R}=c \mathrm{Hex} \\
& \mathrm{R}=\mathrm{Ph}
\end{aligned}
$$<smiles>[R]C1CC(=O)N([Y17])C1</smiles><smiles>[R]COc1ccccc1C(=O)C(C)=N</smiles><smiles>[R]C1Oc2ccccc2C(=O)C1C</smiles>

$$
\mathrm{R}=\mathrm{CH}_{3}, \mathrm{Ph}, \mathrm{CH}=\mathrm{CH}_{2}
$$

Hashimoto and co-workers obtained enantiomeric excesses of $24-76 \%$ ee in the intramolecular $\mathrm{C}-\mathrm{H}$ insertion reactions of $\alpha$-diazo- $\beta$-keto esters 37 catalysed by catalysts of type $\mathbf{8}$, to yield $\beta$-keto esters 38 equation 9 (Hashimoto et al, 1990). More recent results with this catalyst line have afforded good enantioselective routes to azetidinones (Anada and Hashimoto, 1998b) and 2-pyrrolidones (Anada and Hashimoto, 1998a). These successes are exemplified by their syntheses of intermediates for trinem $\beta$ lactam antibiotics 39 and a typical $\mathrm{GABA}_{\mathrm{B}}$ receptor agonist $(R)-(-)$-baclofen $\mathbf{4 0}$ (Scheme 11).

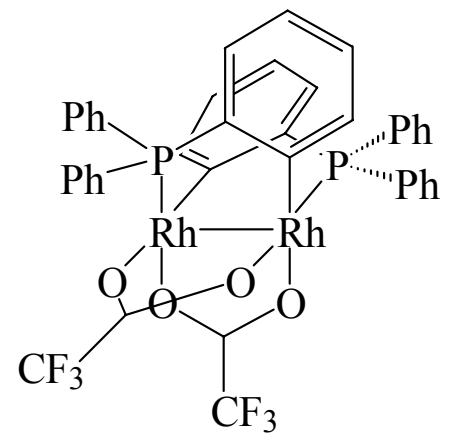

(M)-36

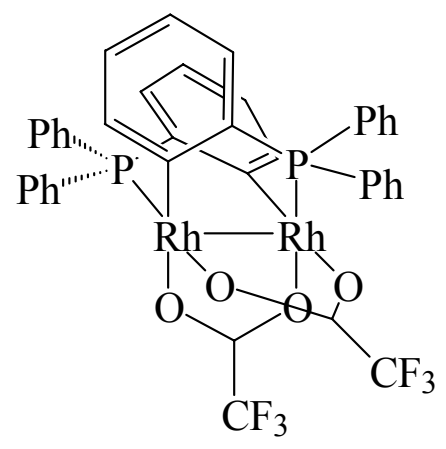

(P)-36 
<smiles>CC(=O)C(=N)C(=O)N1Cc2ccccc2OC12CCCCC2</smiles>

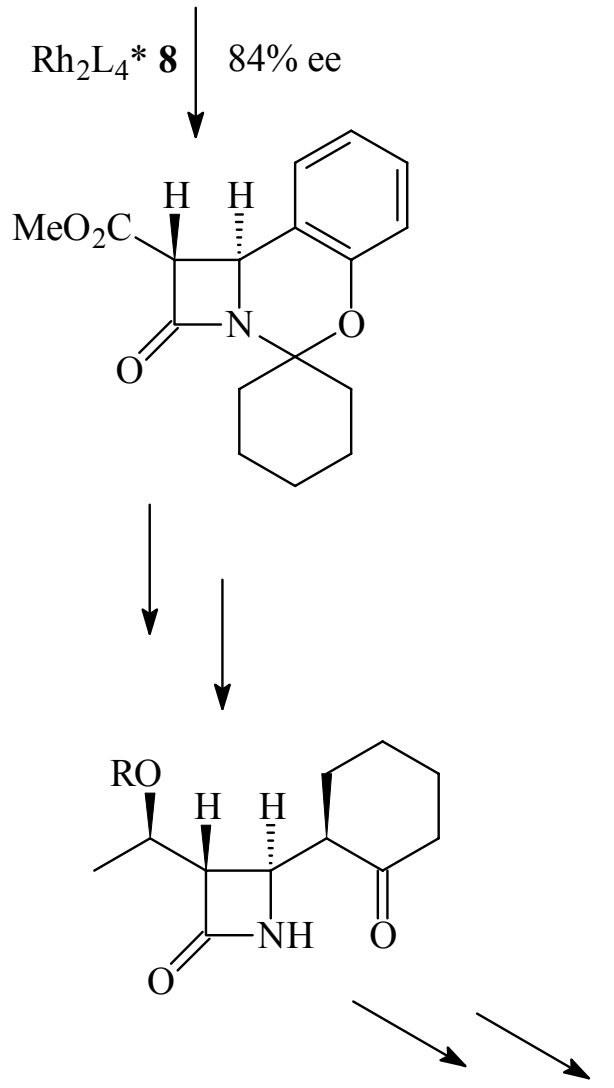<smiles>[R]CCN(C(=O)C(=N)C(C)=O)c1ccc([N+](=O)[O-])cc1</smiles>

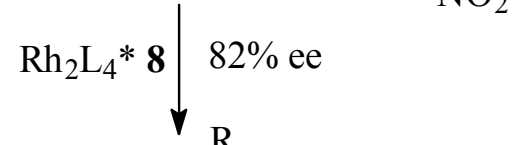<smiles>[R]C1CN(c2ccc([N+](=O)[O-])cc2)C(=O)C1C(C)=O</smiles><smiles>[R]C(CN)C([R])CN</smiles>

40



trinem antibiotics

Scheme 11. Applications of enantioselective intramolecular C-H insertion 
Doyle and co-workers have applied the homochiral dirhodium(II) carboxamidate catalysts to the enantioselective carbon-hydrogen insertion reactions of diazoesters and diazoamides (Doyle et al, 1993c, $1995 b, 1996 \mathrm{c})$. An early application of $\mathrm{Rh}_{2}(5 S-M E P Y)_{4}$ 9a was in the diazo decomposition of alkyl diazoacetates such as $\mathbf{4 1}$ to give the corresponding $\gamma$-lactones $\mathbf{4 2}$ in high yield, since insertion into a C-H bond $\alpha$ to an ether oxygen is a facile process equation 10 (Doyle et al, 1991c). With primary alkyl diazoacetates other than 41, C-H insertion reactions catalysed by $\mathrm{Rh}_{2}(\mathrm{MEPY})_{4}$ proceed with enantioselectivities that are $<70 \%$ ee. However, the introduction of 2-oxoimidazolidine catalyst variants 11 has led to enhanced enantioselectivities and excellent regiocontrol (Doyle et al, 1994f, 1995f-h; Müller and Polleux, 1994; Bode et al, 1996). For example, use of $\mathrm{Rh}_{2}(4 S \text {-MPPIM })_{4} 11 d$ provided $\gamma$-lactones 44 from diazoacetates 43 derived from primary alcohols equation 11. This methodology provided facile access to a series of naturally occuring lignans, for example (-) enterolactone 45, (+)-arctigenin 46 and (+)-isodeoxypodophyllotoxin 47 (Bode et al, 1996).<smiles>[Y]CCCC(=O)C(=[W])C([R])O[R]</smiles>

37<smiles>[R]OC(=O)C1C(=O)CCC1[Y]</smiles>

$38 \quad 24-76 \%$ ee<smiles>[R]OCCOC(=O)C=[W]</smiles>

41

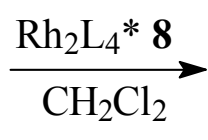

42<smiles>[R20]C1COC(=O)C1</smiles>

$\mathrm{A}=\mathrm{Me}, \mathrm{Ph}, \mathrm{C}_{5} \mathrm{H}_{11}, \mathrm{CH}=\mathrm{CH}_{2}$

$$
\begin{array}{cl}
\mathrm{R}=\mathrm{Me} & 91 \% \text { ee } \\
\mathrm{Et} & 89 \% \text { ee } \\
\mathrm{Bn} & 87 \% \text { ee }
\end{array}
$$

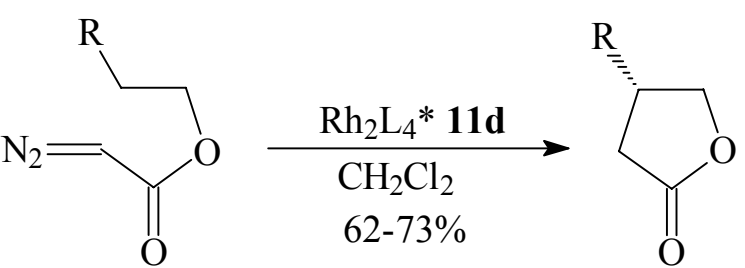

43
$\mathrm{R}=\mathrm{Et} \quad 96 \%$ ee

$i \mathrm{Bu} \quad 95 \%$ ee

Bn $\quad 89 \%$ ee

$m \mathrm{MeOBn} \quad 92 \%$ ee

$3,4-(\mathrm{MeO})_{2} \mathrm{Bn} \quad 94 \%$ ee 
<smiles>O=C1OC[C@H](Cc2cccc(O)c2)[C@@H]1Cc1cccc(O)c1</smiles>

45<smiles>COc1cc(C[C@@H]2COC(=O)[C@H]2Cc2ccc(O)c(OC)c2)ccc1O</smiles>

46<smiles>COc1cc([C@H]2c3cc4c(cc3C[C@H]3COC(=O)[C@H]23)OCO4)cc(OC)c1OC</smiles>

47

This methodology has been applied to the $\mathrm{C}-\mathrm{H}$ insertion reactions of secondary cycloalkyl diazoacetates 48, where diastereoselectivity in the formation of cis- and trans-fused bicyclic lactones 49 and 50 is a critical control feature (Table 10) (Doyle et al, 1994f). Use of $\mathrm{Rh}_{2}(5 S \text {-MEPY })_{4}$ 9a or $\mathrm{Rh}_{2}(4 S$ $\mathrm{MEOX})_{4}$ 10a produced insertion products with a high degree of enantiocontrol, but levels of diastereocontrol were far lower. In the formation of the more strained fused cyclopentyl lactone, only the cis diastereomer is formed, but the levels of enantioselectivity are lower than those obtained with the larger ring-sizes. However, both high enantiocontrol and almost complete stereocontrol were achieved in the latter with the catalyst $\mathrm{Rh}_{2}(4 S \text {-MACIM })_{4}$ 11a (Table 10) (Doyle et al, 1994f).

Investigation of the enantioselective $\mathrm{C}-\mathrm{H}$ insertion reactions of tertiary cycloalkyl diazoacetates 51a,b catalysed by $\mathrm{Rh}_{2}(5 S-\mathrm{MEPY})_{4}$ 9a and $\mathrm{Rh}_{2}(4 S \text {-BNOX })_{4}$ 10c have been carried out equation 12 (Müller and Polleux, 1994). In contrast to the secondary cycloalkyl analogues above (Table 10), both enantioselectivities and yields obtained in the formation of the bicyclic lactones $\mathbf{5 2} \mathbf{a}, \mathbf{b}$ were poor, although only cis products were observed. Again, $\mathrm{Rh}_{2}(4 S \text {-MACIM })_{4}$ led to greatly improved results (Doyle et al, 1995f).

High levels of enantio- and diastereocontrol have been achieved with cis- or trans-4alkylcyclohexyldiazoacetates (Doyle et al, 1994f; Müller and Polleux, 1994), and with 2-adamantyl diazoacetate (Doyle et al, 1995b) in the formation of lactones 53-55 respectively.



$$
\begin{aligned}
51 \text { a } n & =1 \\
\text { b } n & =2
\end{aligned}
$$

52 a $85 \%$ ee b $90 \%$ ee

Doyle and co-workers have described the use of $\mathrm{Rh}_{2}(5 R-\mathrm{MEPY})_{4} R-9 \mathrm{a}$ in the $\mathrm{C}-\mathrm{H}$ insertion reactions of glycerol derived diazoacetates for the convenient synthesis of pure 2-deoxyxylolactone (Scheme 12) (Doyle et al, 1994g). The success of this reaction is probably based on the ether oxygen's 
electronic activation of adjacent C-H bonds (Adams et al, 1989; Wang and Adams, 1994). In the absence of the ether oxygen, enantioselectivities in the $\mathrm{C}-\mathrm{H}$ insertion reactions of alkyl diazoacetates remain high, but diastereocontrol with $\mathrm{Rh}_{2}(\mathrm{MEPY})_{4}$ catalysts tends to be relatively low.<smiles>CC1CC[C@H]2OC(=O)C[C@H]2C1</smiles>

53 98\% ee<smiles>C[C@H]1CC[C@@H]2OC(=O)C[C@H]2C1</smiles>

54 95\% ee<smiles>O=C1CC23CC4CC(CC(C4)[C@H]2O1)C3</smiles>

55 98\% ee

Table 10. Diastereo- and enantioselective intramolecular synthesis of fused bicyclic lactones<smiles>N[CH]C(=O)OC1CCCN1</smiles>

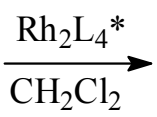<smiles>O=C1C[C@H]2CCC[C@H]2O1</smiles>

49 a-d<smiles>O=C1C[C@H]2CCC[C@H]2O1</smiles>

50 a-d

c $n=3$

d $n=4$

\begin{tabular}{|c|c|c|c|c|}
\hline $\mathbf{4 6}$ & Cat & $\mathbf{4 9 : 5 0}$ & $\mathbf{4 9} \% \mathbf{e e}$ & $\mathbf{5 0} \%$ ee \\
\hline a & $\mathbf{1 1 a}$ & $100: 0$ & 89 & - \\
a & $\mathbf{9 a}$ & $100: 0$ & 40 & - \\
$\mathbf{b}$ & $\mathbf{1 1 a}$ & $99: 1$ & 97 & 65 \\
$\mathbf{b}$ & $\mathbf{9 a}$ & $75: 25$ & 97 & 91 \\
$\mathbf{b}$ & $\mathbf{1 0 a}$ & $55: 45$ & 96 & 95 \\
c & $\mathbf{1 1 a}$ & $99: 1$ & 96 & 61 \\
d & $\mathbf{1 1 a}$ & $99: 1$ & 97 & 59 \\
\hline
\end{tabular}

Dirhodium(II) carboxamidate catalysed C-H insertion reactions of diazoacetamides derived from cyclic amines have been shown to afford $\beta$-lactam products preferentially, with a high degree of enantiocontrol equation 13 (Doyle and Kalinin, 1995i). 
<smiles>N[C+]C(=O)N1CCCCCC1</smiles><smiles>[R12]C(C)(CC)C(=O)O</smiles><smiles>O=C1CC2CCCCCN12</smiles>

$97 \%$ ee<smiles>[R]CC(C[R20])OC([NH])=O</smiles>

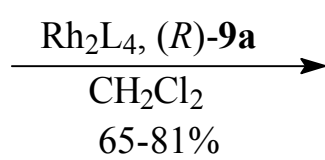

$\mathrm{R}=\mathrm{Me}, 97 \%$ ee $\mathrm{R}=\mathrm{Bn}, 94 \%$ ee

$\mathrm{RO}$<smiles>[R]C1CC(=O)OC1CO</smiles>

$93 \%$

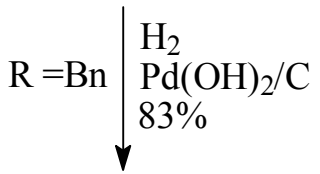

$\mathrm{HO}$<smiles>O=C1C[C@@H]2OC(=O)O[C@@H]2C1</smiles>

2-deoxyxylolactone

Scheme 12. Enantioselective synthesis of 2-deoxyxylolactone

\subsubsection{Heteroatom-Hydrogen Insertion Products}

The insertion of transition metal carbenes, particularly those derived from dirhodium(II) carboxylate catalysts, into a variety of nucleophilic heteroatom-H bonds have provided novel routes to the synthesis of many synthetically relevant compounds (Ye and McKervey, 1994; Doyle et al, 1998a). Of these, insertion into $\mathrm{O}-\mathrm{H}, \mathrm{N}-\mathrm{H}$ and $\mathrm{Si}-\mathrm{H}$ are the most prominent. Asymmetric variants of these reactions are, outside of those that are conducted on enantiomerically pure substrates, still in their infancy. Of the asymmetric variants reported, the diastereoselective chiral auxiliary approach has shown the most success. Recently, Moody and co-workers reported the $\mathrm{Rh}_{2}(\mathrm{OAc})_{4}$ catalysed intermolecular $\mathrm{O}-\mathrm{H}$ insertion reactions of chiral auxiliary-bearing diazoacetates with simple alcohols, with diastereomeric excesses of up to $53 \%$ being attained (Table 11) (Aller et al, 1995; Miller et al, 1999).

To date the N-H insertion reactions reported have shown disappointing levels of asymmetric induction $(<50 \%$ ee $)$, and much more research is required before this becomes a useful synthetic tool (Aller et al, 1996; Garcia et al, 1996). On the other hand, Si-H insertion has shown greater promise. The Landais group (Landais, 1997) has provided the most significant results via a chiral auxiliary approach (Landais et al, 1994a, 1994b; Bulugahapitiya et al, 1997) equations 14, 15. Three groups have independently reported initial successful results in an enantioselective approach with chiral dirhodium 
catalysts, $\mathrm{Rh}_{2}\left(5 S\right.$-MEPY) 9a (Buck et al, 1996; Bulugahapitiya et al, 1997) and $\mathrm{Rh}_{2}(S$-DOSP) 7 (Davies et al, 1997c). The best results equation 16 were obtained with vinyldiazoacetates.<smiles>CC(=[W])C(=O)O[14CH3]</smiles>

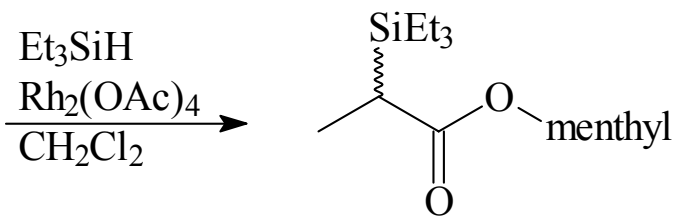

$\mathrm{dr}=72: 28$<smiles>CC/C=C\C(=N)C(=O)O[C@H]1C(=O)OCC1(C)C</smiles>

<smiles>[R]C(=[W])C(=[W])C=C([R])[R]</smiles>

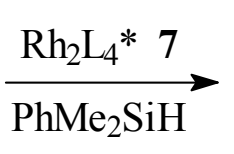<smiles>[R]C([R])=CC([AsH2-])C([R10])[R]</smiles>

$$
\begin{aligned}
& \mathrm{L}=(S \text {-DOSP }) \text { ee } 77-95 \% \\
& \mathrm{~L}=(5 S \text {-MEPY }) \text { ee } 52-72 \%
\end{aligned}
$$

\subsection{Aromatic Cycloaddition and Substitution Products}

Transition metal catalysed carbene addition to aromatic rings may be considered a special class of cyclopropanation reaction. The high-yielding dirhodium(II) catalysed intramolecular reactions of $\alpha$ diazocarbonyl compounds form the fused bicyclic cycloheptatrienes such as $\mathbf{5 6}$ This was reduced to the bicyclodecanone 57 with a determined enantiomeric excess of 33\% equation 17 (Kennedy et al, 1990). Asymmetric success has also been observed using chiral dirhodium(II) phosphates 13a and have yielded enantioselectivities of up to $60 \%$ ee equation 18 (McCarthy et al, 1992).

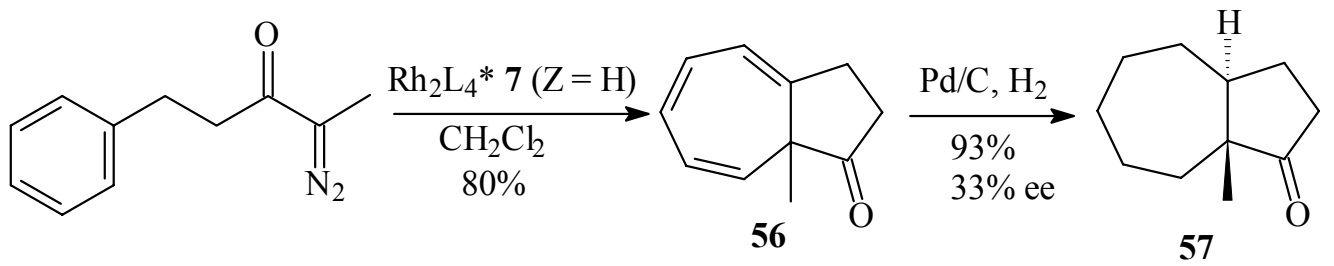


Table 11. Diastereoselective intermolecular O-H insertion by chiral auxiliary-bearing diazoacetates

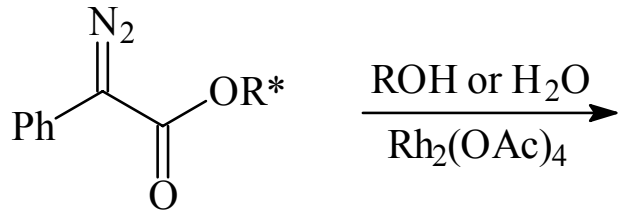<smiles>[R10]C(OC(=O)C([2H])c1ccccc1)c1ccccc1</smiles>

\begin{tabular}{|c|c|c|c|}
\hline $\mathbf{R}^{*}$ & ROH & Yield \% & $\begin{array}{c}\text { dr (major } \\
\text { config) }\end{array}$ \\
\hline & $\mathrm{MeOH}$ & 95 & 52:48 \\
\hline & $\begin{array}{c}\mathrm{H}_{2} \mathrm{O} \\
\mathrm{MeOH} \\
i \mathrm{PrOH}\end{array}$ & $\begin{array}{l}84 \\
75 \\
82\end{array}$ & $\begin{array}{c}50: 50 \\
54: 46(S) \\
62: 38(S)\end{array}$ \\
\hline & $\begin{array}{c}\mathrm{H}_{2} \mathrm{O} \\
\mathrm{MeOH} \\
i \mathrm{PrOH} \\
t \mathrm{BuOH}\end{array}$ & $\begin{array}{l}79 \\
63 \\
85 \\
40\end{array}$ & $\begin{array}{l}666: 34(R) \\
72: 28(R) \\
68: 32(R) \\
76: 24(R)\end{array}$ \\
\hline$N$ & $\begin{array}{c}\mathrm{H}_{2} \mathrm{O} \\
I \mathrm{PrOH}\end{array}$ & $\begin{array}{l}85 \\
71\end{array}$ & $\begin{array}{l}75: 25(S) \\
71: 29(R)\end{array}$ \\
\hline $\begin{array}{c}\xi \\
\mathrm{SO}_{2} \mathrm{~N}(c \mathrm{Hex})_{2}\end{array}$ & $\begin{array}{c}\mathrm{H}_{2} \mathrm{O} \\
i \mathrm{PrOH} \\
t \mathrm{BuOH}\end{array}$ & $\begin{array}{l}98 \\
82 \\
37\end{array}$ & $\begin{array}{l}66: 34(R) \\
74: 26(R) \\
75: 25(R)\end{array}$ \\
\hline
\end{tabular}

The only diastereoselective approach to aromatic cycloaddition involves the recent novel use of a chiral diol auxiliary as a tether between the aromatic substrate and the diazo reagent (Sugimura et al, 1998). This has provided entry into a series of potentially useful tropilidenes as chirons for further synthesis equation 19. 
DIRHODIUM(II) CARBENES: THE CHIRAL PRODUCT CASCADE<smiles>CC(=N)C(=O)c1ccccc1-c1ccccc1</smiles>

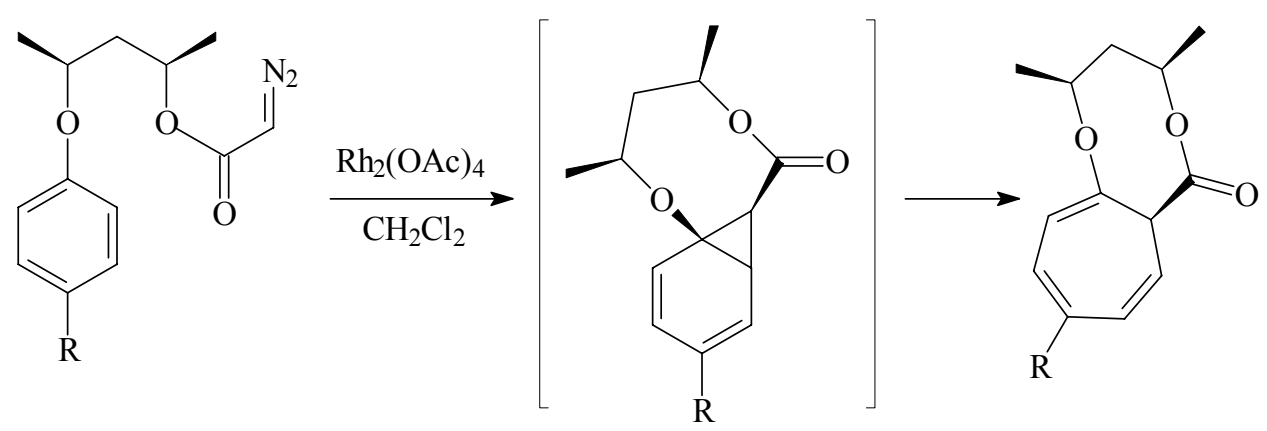

Intramolecular aromatic substitution by metal carbenes represents a formal $\mathrm{C}-\mathrm{H}$ insertion with tremendous potential for asymmetric synthesis via chiral catalysis. Although not many reports have appeared, there is evidence of early success. The Hashimoto group has exploited their amino acid phthalimide catalysts 8 to good effect in the synthesis of a range of indanones (Table 12) (Watanabe et al, 1995, 1996a).

Table 12. Enantioselective intramolecular aromatic substitution<smiles>[R2]C(=N)C(=O)C([R])(c1ccccc1)c1ccccc1</smiles><smiles>[R]C1C(=O)C([R])(c2ccccc2)c2ccccc21</smiles>

\begin{tabular}{|c|c|c|c|}
\hline $\mathbf{R}_{\mathbf{1}}$ & $\mathbf{R}_{\mathbf{2}}$ & $\mathbf{5 8}$ yield \% & $\mathbf{5 8}$ \% ee \\
\hline $\mathrm{Me}$ & $\mathrm{H}$ & 75 & 88 \\
$\mathrm{Et}$ & $\mathrm{H}$ & 86 & 95 \\
$n \mathrm{Pr}$ & $\mathrm{H}$ & 74 & 98 \\
allyl & $\mathrm{H}$ & 70 & 88 \\
$\mathrm{Me}$ & $\mathrm{CO}_{2} \mathrm{Me}$ & 87 & 93 \\
\hline
\end{tabular}


The same workers have exploited this protocol in the synthesis of the aspartate receptor antagonist FR 115427 (Scheme 13) (Watanabe et al, 1996a).<smiles>CC(=O)C(=N)C(=O)C(C)(c1ccccc1)c1ccccc1</smiles>

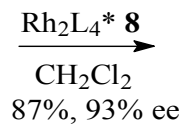

$87 \%, 93 \%$ ee<smiles>CC(=O)C1C(=O)C(C)(c2ccccc2)c2ccccc21</smiles><smiles>CC1(c2ccccc2)NCCc2ccccc21</smiles>

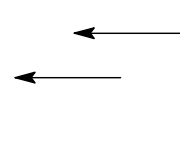<smiles>CC(=O)Cc1ccccc1C(C)(C(C)=O)c1ccccc1</smiles>

Scheme 13. Synthesis of antagonist FR 115427 via intramolecular aromatic substitution

\subsection{Ylide Cascade Products}

Metal carbenes derived from $\alpha$-diazocarbonyl compounds are electrophilic enough to add to heteroatoms and form ylides equation 20. These then may undergo a wide range of reactions including [2,3]-sigmatropic rearrangements, [1,2]-insertion (Stevens rearrangements), hydride elimination, and dipolar cycloaddition (Doyle and Forbes, 1998e; Doyle et al, 1998a). This diverse reactivity, along with their often-competitive initial formation, has contributed to the relatively barren landscape in terms of their dirhodium-catalysed asymmetric synthesis. Successful asymmetric adaptation is only a very recent achievement, and is so far restricted to oxonium ylide systems.<smiles>[R][Y]([R])=[W]</smiles>

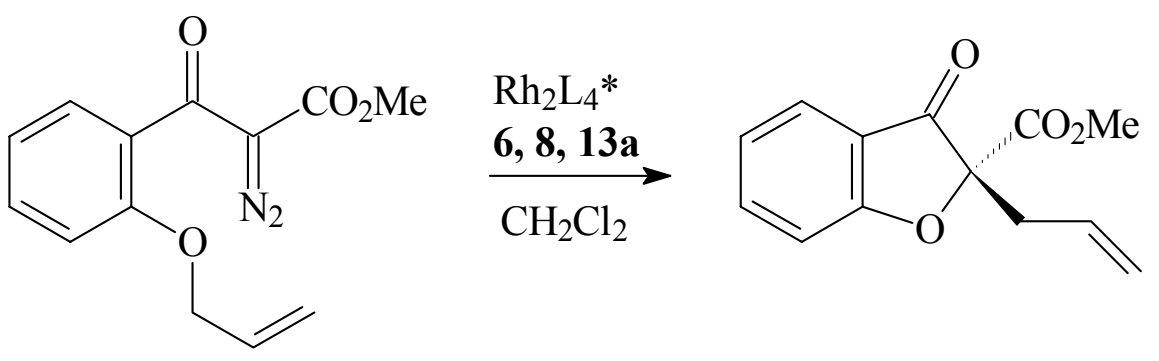


The initial examples were provided by the McKervey group who exploited a tandem ylide formation-[2,3]-sigmatropic rearrangement sequence to produce benzofuranone derivatives with up to $60 \%$ ee equation 21 (McCarthy et al, 1992; Pierson et al, 1997).

Dirhodium(II) carboxamidate catalysts were used in initial studies of catalytic asymmetric tandem ylide formation-cycloaddition (Doyle and Forbes, 1998e; Suga et al, 1998). However, these only produced ee values of $<30 \%$. Very recent developments have produced the first examples with ee values approaching synthetically useful levels. Thus diazo ketoesters were induced to give intramolecular cycloadducts with ee's up to 53\% equation 22 (Hodgson et al, 1997). The Hashimoto group has taken this development further with diazo ketones in the intermolecular cycloaddition to afford bridged bicyclic skeletons in good yield and high enantioselectivity equation 23 (Kitigaki et al, 1999).<smiles>[R]OC(=O)C(=[W])C(=O)CCC(=O)CCCCC=C</smiles>

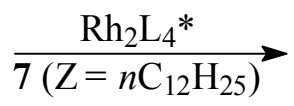

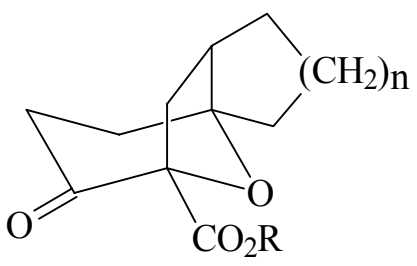

The Doyle group has provided the best enantioselective (ee up to 88\%) example of ylide formation[1,2]-insertion in their report on the decomposition of 1,3-dioxane diazoacetates equation 24 (Doyle et al, 1997e).<smiles>N=CC(=O)CCC(=O)c1ccccc1</smiles><smiles>COC(=O)C#CCCC(C)(C)OC(C)(C)C</smiles><smiles>CC(=O)C1=C(C(C)=O)C2(c3ccccc3)CCC(=O)C1O2</smiles><smiles>CC1(C)COCC(C)(OC(=O)C=[NH2+])CO1</smiles>

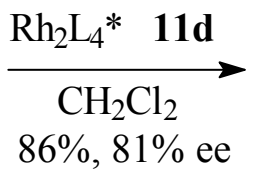<smiles>CC12CCC(C)(C)C(OC1)C(=O)C2</smiles>

\section{Conclusion}

Over the past decade, the reports of chiral dirhodium(II) catalyst systems and their applications to asymmetric synthesis have burgeoned. As this technology is applied to a greater diversity of reaction systems, it seems inevitable that the spectrum of dirhodium(II)-carbene chemistry will continue to 
expand. Given the wide range of non-racemic products that can be targeted in this way, these developments auger well for asymmetric organic synthesis and the industries that depend thereon.

\section{Note added in proof}

The readers' attention is drawn to the following noteworthy contributions which have appeared since original submission. Doyle et al (1999d) - intramolecular addition to remote furans; Davies and Panaro (1999) - improved $\mathrm{D}_{2}$-symmetric dirhodium(II) tetraprolinate cyclopropanation catalysts; Doyle et al (2000) - macrocycle formation via intramolecular cyclopropanation.

\section{References}

ADAMS, J., POUPART, M.-A., GRENIER, L., SCHALLER, C., OUIMET, N. and FRENETTE, R. 1989. Rhodium Acetate Catalyzes the Addition of Carbenoids $\alpha$ - to Ether Oxygens. Tetrahedron Lett. 30: 1749-1752.

AHSAN, M. Q., BERNAL, I. and BEAR, J. L. 1986. Reaction of $\mathrm{Rh}_{2}\left(\mathrm{OOCCH}_{3}\right)_{4}$ with Acetamide: Crystal and Molecular Structure of $\left[\mathrm{Rh}_{2}\left(\mathrm{NHOCCH}_{3}\right)_{4} \cdot 2 \mathrm{H}_{2} \mathrm{O}\right] \cdot 3 \mathrm{H}_{2} \mathrm{O}$. Inorg. Chem. 25: 260-265.

AGER, D. J. and EAST, M. B. 1996. Asymmetric Synthetic Methodology. CRC Press, New York

ALLER, E., BROWN, D. S., COX, G. G., MILLER, D. J. and MOODY, C. J. 1995. Diastereoselectivity in the O-H Insertion Reactions of Rhodium Carbenoids Derived from Phenyldiazoacetates of Chiral Alcohols. J. Org. Chem. 60: 4449-4460.

ALlER, E., BUCK, R. T., DRYSDALE, M. J., FERRIS, L., HAIGH, D., MOODY, C. J., PEARSON, N. D. and SANGHERA, J. B. 1996. N-H Insertion Reactions of Rhodium Carbenoids. Part 1. Preparation of $\alpha$-Amino Acis and $\alpha$-Aminophosphonic Acid Derivatives. J. Chem. Soc., Perkin Trans. 1 : 2879-2884.

ANADA, M. and HASHIMOTO, S. 1998a. Enantioselective Synthesis of 4-Substituted 2-Pyrrolidinones by Siteselective $\mathrm{C}-\mathrm{H}$ Insertion of $\alpha$-Methoxycarbonyl- $\alpha$-diazoacetanilides Catalysed by Dirhodium(II) Tetrakis $[N$ phthaloyl-(S)-tert-leucinate]. Tetrahedron Lett. 39: 79-82.

ANADA, M. and HASHIMOTO, S. 1998b. Enantioselective Intramolecular C-H Insertion Route to a Key Intermediate for the Synthesis of Trinem Antibiotics. Tetrahedron Lett. 39: 9063-9066.

BAIRD, M. S. 1988. Functionalized Cyclopropenes as Synthetic Intermediates. Top. Curr. Chem. 144: 137-209.

BINGER, P. and BÜCH, H. M. 1987. Cyclopropenes and Methylenecyclopropanes as Multifunctional Reagents in Transition Metal Catalysed Reactions. Top. Curr. Chem. 135: 77-151.

BODE, J. W., DOYLE, M. P., PROTOPOPOVA, M. N. and ZHOU, Q.-L. 1996. Intramolecular Regioselective Insertion into Unactivated Prochiral Carbon-Hydrogen Bonds with Diazoacetates of Primary Alcohols Catalyzed by Chiral Dirhodium(II) Carboxamidates. Highly Enantioselective Synthesis of Natural Lignan Lactones. J. Org. Chem. 61: 9146-9155.

BOYAR, E. B. and ROBINSON, S. D. 1983. Rhodium(II) Carboxylates. Coord. Chem. Rev. 50: 109-208.

BRUNNER, H., KLUSCHANZOFF, H. and WUTZ, K. 1989. Enantioselective Catalysis. 47. Rhodium(II)Carboxylate Complexes and their Use in Enantioselective Cyclopropanation. Bull. Chem. Soc. Belg. 98: 63-72.

BRUNNER, H. and ZETTLMEIER, W. 1993. Handbook of Enantioselective Catalysis with Transition Metal Compounds, Vols. I, II. VCH, Weinheim.

BUCK, R. T., DOYLE, M. P., DRYSDAlE, M. J., FERRIS, L., FORBES, D.C., HAIGH, D., MOODY, C. J., PEARSON, N. D., and ZHOU, Q.-L. 1996. Asymmetric Rhodium Carbenoid Insertion into the Si-H Bond. Tetrahedron Lett. 37: 7631-7634.

BUCK, R. T., COE, D. M., DRYSDALE, M. J., MOODY, C. J., and PEARSON, N. D. 1998. Parallel Synthesis Techniques in the Identification of New Chiral Dirhodium(II) Carboxylates for Asymmetric Carbenoid Insertion Reactions. Tetrahedron Lett. 39: 7181-7184.

BULUGAHAPITIYA, P., LANDAIS, Y., PARRA-RAPADO, L., PLANCHENAULT, D. and WEBER, V. 1997. A Stereospecific Access to Allylic Systems Using Rhodium(II)-Vinyl Carbenoid Insertion into Si-H, O-H, and NH Bonds. J. Org. Chem. 62: 1630-1641.

BURGESS, K. and HO, T.-L. 1994. Asymmetric Syntheses of 2,3-Methanoamino Acids. Synlett. pp 575-583.

BURKE, S. D. and GRIECO, P. A. 1979. Intramolecular Reactions of Diazocarbonyl Compounds. Org. React. 26: 361-475. 


\section{DIRHODIUM(II) CARBENES: THE CHIRAL PRODUCT CASCADE}

CALDWELL, R. A. and ZHOU, L. 1994. Are Perpendicular Alkene Triplets Just 1,2-Biradicals? Studies with the Cyclopropylcarbinyl Clock. J. Am. Chem. Soc. 116: 2271-2275.

COREY, E. J. and GRANT, T. G. 1994. A Catalytic Enantioselective Route to the Important Antidepressant Sertraline. Tetrahedron Lett. 35: 5373-5376.

DAVIES, H. M. L. 1991. Addition of Ketocarbenes to Alkenes, Alkynes and Aromatic Systems. In Comprehensive Organic Synthesis. Chap. 4.8, pp 1031-1067. Ed. Trost, B. M. Pergamon Press, New York.

DAVIES, H. M. L. 1993a. Tandem Cyclopropanation/Cope Rearrangement: A General Method for the Construction of Seven-Membered Rings. Tetrahedron. 49: 5203-5223.

DAVIES, H. M. L. and HUTCHESON, D. K. 1993b. Enantioselective Synthesis of Vinylcyclopropanes by Rhodium(II) Catalysed Decomposition of Vinyldiazomethanes in the presence of Alkenes. Tetrahedron Lett. 34: 7243-7246.

DAVIES, H. M. L., HUBY, N. J. S., CANTRELL, W. R. and OLIVE, J. L. 1993c. $\alpha$-Hydroxy Esters as Chiral Auxiliaries in Asymmetric Cyclopropanations by Rhodium(II)-Stabilized Vinylcarbenoids. J. Am. Chem. Soc. 115: 9468-9479.

DAVIES, H. M. L., SAIKALI, E., HUBY, N. J. S., GILlIATT, V. J., MATSAI, J.J., SEXTON, T. and CHILDERS, S.R. 1994a. Synthesis of 2 $\beta$-Acyl-3 $\beta$-aryl-8azabicyclo[3.2.1]octanes and Their Binding Affinities at Dopamine and Seratonin Transport Sites in Rat Striatum and Frontal Cortex. J. Med. Chem. 37: 1262-1268.

DAVIES, H. M. L., PENG, Z.-Q. and HOUSER, J. H. 1994b. Asymmetric Synthesis of 1,4-Cycloheptadienes and Bicyclo[3.2.1]octa-2,6-dienes by Rhodium(II) $N$-[p-(tert-Butyl)phenylsulfonyl]prolinate Catalysed Reactions Between Vinyldiazomethanes and Dienes. Tetrahedron Lett. 35: pp 8939-8942.

DAVIES, H. M. L., AHMED, G. and CHURCHILL, M. R. 1996a. Asymmetric Synthesis of Highly Functionalized 8-Oxabicyclo[3.2.1]octene Derivatives. J. Am. Chem. Soc. 118: 10774-10782.

DAVIES, H. M. L., BRUZINSKI, P. R., LAKE, D. H., KONG, N. and FALL, M. J. 1996b. Asymmetric Cyclopropanations by Rhodium(II) $N$-(Arylsulfonyl)prolinate Catalyzed Decomposition of Vinyldiazomethanes in the Presence of Alkenes. Practical Enantioselective Synthesis of the Four Stereoisomers of 2-Phenylcyclopropan-1-amino Acid. J. Am. Chem. Soc. 118: 6897-6907.

DAVIES, H. M. L., KUHN, L. A., THORNLEY, C., MATASI, J. J., SEXTON, T. and CHILDERS, S. R. 1996c. Synthesis of 3- $\beta$-Aryl-8-azabicyclo[3.2.1] octanes with High Binding Affinities and Selectivities for the Serotonin Transporter Site. J. Med. Chem. 39: 2554-2558.

DAVIES, H. M. L., BRUZINSKI, P. R. and FALL, M. J. 1996d. Effect of Diazoalkane Structure on the Stereoselectivity of Rhodium(II) (S)-N-(Arylsulfonyl)prolinate Catalyzed Cyclopropanations. Tetrahedron Lett. 37: 4133-4136.

DAVIES, H. M. L., DOAN, B. D. 1996. Asymmetric Synthesis of the Tremulane Skeleton by a Tandem Cyclopropanation/Cope Rearrangement. Tetrahedron Lett. 37: 3967-3970.

DAVIES, H. M. L. 1997a. Asymmetric Synthesis Using Rhodium-Stabilized Vinylcarbenoid Intermediates. Aldrichimica Acta.30: 107-114.

DAVIES, H. M. L., MATASI, J. J., HODGES, L. M., HUBY, N. J. S., THORNLEY, C, KONG, N. and HOUSER, J. H. 1997b. Enantioselective Synthesis of Functionalized Tropanes by Rhodium(II) Carboxylate-Catalyzed Decomposition of Vinyldiazomethanes in the Presence of Pyrroles. J. Org. Chem. 62: 1095-1105.

DAVIES, H. M. L., HANSEN, T., RUTBERG, J. and BRUZINSKI, P. R. 1997c. Rhodium(II) (S)-N(Arylsulfonyl)prolinate Catalyzed Asymmetric Insertions of Vinyl- and Phenylcarbenoids into the Si-H Bond. Tetrahedron Lett. 38: 1741-1744.

DAVIES, H. M. L., AHMED, G., CALVO, R. L., CHURCHILL, M. R. and CHURCHILL, D. G. 1998a. Asymmetric Synthesis of 2,3-Dihydrofurans by Reaction of Rhodium-Stabilized Vinylcarbenoids with Vinyl Ethers. J. Org. Chem. 63: 2641-2645.

DAVIES, H. M. L., KONG, N. and CHURCHILL, M. R. 1998b. Asymmetric Synthesis of Cyclopentenes by [3 + 2] Annulations between Vinylcarbenoids and Vinyl Ethers. J. Org. Chem. 63: 6586-6589.

DAVIES, H. M. L., and PANARO, S. A. 1999. Novel Dirhodium Tetraprolinate Catalysts Containing Bridging Prolinate Ligands for Asymmetric Carbenoid Reactions. Tetrahedron Lett. 40: 5287-5290.

DEMONCEAU, A., NOELS, A. F., HUBERT, A. J. and TEYSSIE, P. 1981. Transition-Metal-Catalysed Reactions of Diazoesters. Insertion into C-H Bonds of Paraffins by Carbenoids. J. Chem. Soc., Chem. Comm. pp 688-689.

DEMONCEAU, A., NOELS, A. F., HUBERT, A. J. and TEYSSIE, P. 1984. Transition-Metal-Catalysed Reactions of Diazoesters. Insertion into C-H Bonds of Paraffins Catalysed by Bulky Rhodium(II) Carboxylates: Enhanced Attack on Primary C-H Bonds. Bull. Soc. Chim. Belg. 93: 945-948.

DOYLE, M. P. 1986. Catalytic Methods for Metal Carbene Transformations. Chem. Rev. 86: 919-939. 
DOYLE, M. P., TAUNTON, J. and PHO, H. Q. 1989a. Conformational and Electronic Preferences in Rhodium(II) Carboxylate and Rhodium(II) Carboxamide Catalysed Carbon-Hydrogen Insertion Reactions of $N, N$ Disubstituted Diazoacetoacetamides. Tetrahedron Lett. 30: 5397-5400.

DOYLE, M. P., BAGHERI, V., PEARSON, M. M. and EDWARDS, J. D. 1989b. Highly Selective $\gamma$-Lactone Synthesis by Intramolecular Carbenoid Carbon-Hydrogen Insertion in Rhodium(II) Carboxylate and Rhodium(II) Carboxamide Catalysed Reactions of Diazo Esters. Tetrahedron Lett. 30: 7001-7004.

DOYLE, M. P., BAGHERI, V., WANDLESS, T. J., HARN, N. K., BRINKER, D. A., EAGLE, C. T. and LOH, K.-L. 1990. Exceptionally High Trans (Anti) Stereoselectivity in Catalytic Cyclopropanation Reactions. J. Am. Chem. Soc. 112: 1906-1912.

DOYLE, M. P., PIETERS, R. J., TAUNTON, J., PHO, H. Q., PADWA, A., HERTZOG, D. L. and PRECEDO, L. 1991a. Synthesis of Nitrogen-Containing Polycycles via Rhodium(II)-Induced Cyclization-Cycloaddition and Insertion Reactions of $\mathrm{N}$-(Diazoacetoacetyl)amides. Conformational Control of Reaction Selectivity. J. Org. Chem. 56: 820-829.

DOYLE, M. P., PIETERS, R. J., MARTIN, S. F., AUSTIN, R. E., OALMANN, C. J. and MÜLLER, P. 1991b. High Enantioselectivity in the Intramolecular Cyclopropanation of Allyl Diazoacetates Using a Novel Rhodium(II) Catalyst. J. Am. Chem. Soc. 113: 1423-1424.

DOYLE, M. P., VAN OEVEREN, A., WESTRUM, L. J., PROTOPOPOVA, M. N. and CLAYTON, T. W. 1991c. Asymmetric Synthesis of Lactones with High Enantioselectivity by Intromolecular Carbon-Hydrogen Insertion Reaction of Alkyl Diazoacetates Catalyzed by Chiral Rhodium(II) Carboxamides. J. Am. Chem. Soc. 113: 8982-8984.

DOYLE, M. P. 1992. Electronic and Steric Control in Intramolecular Carbon-Hydrogen Insertion Reactions of Diazo Compounds Catalysed by Rhodium(II) Carboxylates and Carboxamides. In Homogeneous Transition Metal Catalysts in Organic Synthesis. Eds W. R. Moser and D. W. Slocum. ACS Advanced Chemistry Series 230, American Chemical Society, Washington, pp 443-461.

DOYLE, M. P. 1993a. Asymmetric Cyclopropanation. In Catalytic Asymmetric Synthesis. Ed. I. Ojima. VCH, Weinheim.

DOYle, M. P., WeStrum, L. J., WOLthUiS, W. N. E., SEE, M. M., BOONE, W. P., BAGHERI, V. and PEARSON, M. M. 1993b. Electronic and Steric Control in Carbon-Hydrogen Insertion Reactions of Diazoacetates Catalysed by Dirhodium(II) Carboxylates and Carboxamides. J. Am. Chem. Soc. 115: 958-964.

DOYLE, M. P., WINCHESTER, W. R., HOORN, J. A. A., LYNCH, V., SIMONSEN, S. H. and GHOSH, R. 1993c. Dirhodium(II) Tetrakis(carboxamidates) with Chiral Ligands. Structure and Selectivity in Catalytic MetalCarbene Transformations. J. Am. Chem. Soc. 115: 9968-9978.

DOYLE, M. P., WINCHESTER, W. R., PROTOPOPOVA, M. N., MÜLlER, P., BERNARDINELLI, G., ENE, D. and MOTALLEBI, S. 1993d. Tetrakis[4(S)-4-phenyloxazolidin-2-one]dirhodium(II) and Its Catalytic Application for Metal Carbene Transformations. Helv. Chim. Acta. 76: 2227-2235.

DOYLE, M. P., PROTOPOPOVA, M. N., BRANDES, B. D., DAVIES, H. M. L., HUBY, N. J. and WHITESELL, J. K. 1993e. Diastereoselectivity Enhancement in Cyclopropanation and Cyclopropenation Reactions of Chiral Diazoacetate Esters Catalysed by Chiral Dirhodium(II) Carboxamides. Synlett. pp 151-153.

DOYLE, M. P. 1994a. Highly Enantioselective Syntheses from Diazocarbonyl Compounds Catalysed by Chiral Dirhodium(II) Carboxamides. Chim. Oggi. pp 13-20.

DOYLE, M. P. 1994b. Asymmetric Syntheses with Catalytic Enantioselective Metal Carbene Transformations. Russ. Chem. Bull. 43: 1770-1782.

DOYLE, M. P., WINCHESTER, W. R., SIMONSEN, S. H. and GHOSH, R. 1994c. Dirhodium(II) Tetrakis[N, $N$ dimethyl-2-pyrrolidone-(5S)-carboxamide]. Structural Effects on Enantioselection in Metal Carbene Transformations. Inorg. Chim. Acta. 220: 193-199.

DOYLE, M. P., PROTOPOPOVA, M. N., MÜLlER, P., ENE, D. G. and SHAPIRO, E. A. 1994d. Effective Uses of Dirhodium(II) Tetrakis[methyl 2-oxopyrrolidine-5(R or $S)$-carboxylate] for Highly Enantioselective Intermolecular Cyclopropenation Reactions. J. Am. Chem. Soc. 116: 8492-8498.

DOYLE, M. P., EISMONT, M. Y., PROTOPOPOVA, M. N. and KWAN, M. M. Y. 1994e. Enantioselective Intramolecular Cyclopropanation of $N$-Allylic and $N$-Homoallylic Diazoacetamides Catalysed by Chiral Dirhodium(II) Catalysts. Tetrahedron. 50: 4519-4528.

DOYLE, M. P., ZHOU, Q.-L., RAAB, C. E., ROOS, G. H. P., CAÑAS, F., PIERSON, D. A., VAN BASTEN, A., MÜLlER, P. and POLLEUX, P. 1994f. Diastereocontrol for Highly Enantioselective Carbon-Hydrogen Insertion Reactions of Cycloalkyl Diazoacetates. J. Am. Chem. Soc. 116: 4507-4508. 


\section{DIRHODIUM(II) CARBENES: THE CHIRAL PRODUCT CASCADE}

DOYLE, M. P., DYATKIN, A. B. and TEDROW, J. S. 1994g. Synthesis of 2-Deoxylolactone from Glycerol Derivatives via Highly Enantioselective Carbon-Hydrogen Insertion Reactions. Tetrahedron Lett. 35: $3853-$ 3856.

DOYLE, M. P. 1995a. Metal Carbene Complexes in Organic Synthesis: Diazodecomposition - Insertion and Ylide Chemistry. In Comprehensive Organometallic Chemistry II, Vol. 12. Chaps. 5.1, 5.2. Ed L. S. Hegedus. Pergamon Press, New York.

DOYLE, M. P., DYATKIN, A. B., PROTOPOPOVA, M. N., YANG, C. I., MIERTSCHIN, C. S., WINCHESTER, W. R., SIMONSEN, S. H., LYNCH, V. and GHOSH, R. 1995b. Enhanced Enantiocontrol in Catalytic Metal Carbene Transformations with Dirhodium(II) Tetrakis[methyl 2-oxoxazolidin-4(S)-carboxylate], $\mathrm{Rh}_{2}(4 \mathrm{~S}-$ MEOX) 4 . Recl. Trav. Chim. Pays-Bas. 114: 163-170.

DOYLE, M. P., AUSTIN, R. E., BAILEY, A. S., DWYER, M. P., DYATKIN, A. B., KALININ, A. V., KWAN, M. M. Y., LIRAS, S., OALMANN, C. J., PIETERS, R. J., PROTOPOPOVA, M. N., RAAB, C. E., ROOS, G. H. P., ZHOU, Q.-L. and MARTIN, S. F. 1995c. Enantioselective Intramolecular Cyclopropanations of Allylic and Homoallylic Diazoacetates and Diazoacetamides Using Chiral Dirhodium(II) Carboxamide Catalysts. J. Am. Chem. Soc. 117: 5763-5775.

DOYLE, M. P., ZHOU, Q.-L., DYATKIN, A. B. and RUPPAR, D. A. 1995d. Enhancement of Enantiocontrol/Diastereocontrol in Catalytic Intramolecular Cyclopropanation and Carbon-Hydrogen Insertion Reactions of Diazoacetates with $\mathrm{Rh}_{2}(4 S \text {-MPPIM })_{4}$. Tetrahedron Lett. 36: 7579-7582.

DOYLE, M. P. and ZHOU, Q.-L. 1995e. Enantioselective Catalytic Intramolecular Cyclopropanation of Allylic $\alpha$ Diazopropionates Optimized with Dirhodium(II) Tetrakis[methyl 2-oxazolidinone-4(S or $R$ )-carboxylate. Tetrahedron: Asymmetry. 6: 2157-2160.

DOYLE, M. P., ZHOU, Q.-L., RAAB, C. E. and ROOS, G. H. P. 1995f. Improved Enantioselection for Chiral Dirhodium(II) Carboxamide-Catalyzed Carbon-Hydrogen Insertion Reactions of Tertiary Alkyl Diazoacetates. Tetrahedron Lett. 36: 4745-4748.

DOYLE, M. P., PROTOPOPOVA, M. N., ZHOU, Q.-L., BODE, J. W., SIMONSEN, S. H. and LYNCH, V. 1995g. Optimization of Enantiocontrol for Carbon-Hydrogen Insertion with Chiral Dirhodium(II) Carboxamidates. Synthesis of Natural Dibenzylbutyrolactone Lignans from 3-Aryl-1-propyl Diazoacetates in High Optical Purity. J. Org. Chem. 60: 6654-6655.

DOYLE, M. P. and KALININ, A. V. 1995h. Enantiomer Differentiation in Intramolecular Carbon-Hydrogen Insertion Reactions of Racemic Secondary Alkyl Diazoacetates Catalyzed by Chiral Dirhodium(II) Carboxamidates. Russ. Chem. Bull. 44: 1729-1734.

DOYLE, M. P. and KALININ, A. V. 1995i. Highly Enantioselective Route to $\beta$-Lactams via Intramolecular C-H Insertion Reactions of Diazoacetylazacycloalkanes Catalyzed by Chiral Dirhodium(II) Carboxamidates. Synlett. pp 1075-1076.

DOYLE, M. P. 1996a. Chiral Dirhodium Carboxamidates. Catalysts for Highly Enantioselective Syntheses of Lactones and Lactams. Aldrichimica Acta, 29: 3-11.

DOYLE, M. P., ZHOU, Q.-L., CHARNSANGAVEJ, C., LONGORIA, M. A., McKERVEY, M. A. and GARCÍA, C. F. 1996b. Chiral Catalysts for Enantioselective Intermolecular Cyclopropanation Reactions with Methyl Phenyldiazoacetate. Origin of the Solvent Effect in Reactions Catalysed by Homochiral Dirhodium(II) Prolinates. Tetrahedron Lett. 37: 4129-4132.

DOYLE, M. P., ZHOU, Q.-L., RAAB, C. E., ROOS, G. H. P., SIMONSEN, S. H. and LYNCH, V. 1996c. Synthesis and Structures of (2,2-cis)-Dirhodium(II) Tetrakis[methyl 1-acyl-2-oxoimidazolidine-4(S)-carboxylates]. Chiral Catalystsbfor Highly Stereoselective Metal Carbene Transformations. Inorg. Chem. 35: 6064-6073.

DOYLE, M. P.,ZHOU, Q.-L., SIMONSEN, S. H. and LYNCH, V. 1996d. Dirhodium(II) Tetrakis[alkyl 2oxoazetidine-4(S)-carboxylates]. A New Set of Effective Chiral Catalysts for Asymmetric Intermolecular Cyclopropanation Reactions with Diazoacetates. Synlett. pp 697-698.

DOYLE, M. P., WINCHESTER, W. R., PROTOPOPOVA, M. N., KAZALA, A. P. and WESTRUM, L. J. 1996e. $(1 R, 5 S)$-(-)6,6-Dimethyl-3-oxabicyclo[3.1.0]hexan-2-one. Highly Enantioselective Intramolecular Cyclopropanation Catalysed by Dirhodium(II) Tetrakis[methyl 2-pyrrolidone-5(R)-carboxylate]. Org. Synth. 73: $13-24$

DOYLE, M. P. and KALININ, A. V. 1996f. Highly Enantioselective Intramolecular Cyclopropanation Reactions of $N$-Allylic- $N$-methyldiazoacetamides Catalysed by Chiral Dirhodium(II) Carboxamidates. J. Org. Chem. 61: 2179-2184.

DOYLE, M. P. and McKeRVEY, M. A. 1997a. Recent Advances in Stereoselective Synthesis Involving Diazocarbonyl Intermediates. Chem. Commun. pp 983-989. 
DOYLE, M. P., RAAB, C. E., ROOS, G. H. P., LYNCH, V. and SIMONSEN, S. H. 1997b. (4,0)-Dirhodium(II) Tetrakis[methyl 1-acetyl-2-oxoimidazolidine-4(S)-carboxylate]. Implication for the Mechanism of Ligand Exchange Reactions. Inorg. Chim. Acta. 266: 13-18.

DOYLE, M. P., PETERSON, C. S., ZHOU, Q.-L. and NISHIYAMA, H. 1997c. Comparative Evaluation of Enantiocontrol for Intramolecular Cyclopropanation of Diazoacetates with Chiral $\mathrm{Cu}(\mathrm{I}), \mathrm{Rh}(\mathrm{II})$ and $\mathrm{Ru}(\mathrm{II})$ Catalysts. Chem. Commun. pp 211-212.

DOYLE, M. P., EISMONT, M. Y. and ZHOU, Q.-L. 1997d. Enantiocontrol in Intramolecular Cyclopropanation of Diazoketones. Conformational Control of Metal Carbene Alignment. Russ. Chem. Bull. 46: 955-958.

DOYLE, M. P., ENE, D. G., FORBES, D. C. and TEDROW, J. S. 1997e. Highly Enantioselective Oxonium Ylide Formation and Stevens Rearrangement Catalyzed by Chiral Dirhodium(II) Carboxamidates. Tetrahedron Lett. 38: 4367-4370.

DOYLE, M. P., McKeRVEY, M. A. and TAO, Y. 1998a. Modern Catalytic Methods for Organic Synthesis with Diazo Compounds. Wiley, New York.

DOYLE, M. P. 1998b. Catalysis with Dirhodium(II) Complexes. In Catalysis by Di- and Polynuclear Metal Cluster Complexes. Eds R. D. Adams and F. A. Cotton. Wiley-VCH, New York.

DOYLE, M. P. 1998c. New Catalysts and Methods for Highly Enantioselective Metal Carbene Reactions. Pure \& Appl. Chem. 70: 1123-1128.

DOYLE, M. P. and PROTOPOPOVA, M. N. 1998d. New Aspects of Catalytic Asymmetric Cyclopropanation. Tetrahedron. 54: 7919-7946.

DOYLE, M. P. and FORBES, D. C. 1998e. Recent Advances in Asymmetric Catalytic Metal Carbene Transformations. Chem. Rev. 98: 911-935.

DOYLE, M. P. 1999a. Control of Enantioselectivity in Catalytic Metal Carbene Reactions. Enantiomer. 4: 621-632.

DOYLE, M. P., ENE, D. G., FORBES, D. C. and PILLOW, T. H. 1999b. Chemoselectivity and Enantiocontrol in Catalytic Intramolecular Metal Carbene Reactions of Diazo Acetates Linked to Reactive Functional Groups by Naphthalene-1,8-dimethanol. Chem. Commun. pp 1691-1692.

DOYLE, M. P., ENE, PETERSON, C. S. and LYNCH, V. 1999c. Macrocyclic Cyclopropenes by Highly Enantioselective Intromolecular Addition of Metal Carbenes to Alkynes. Angew. Chem., Int. Ed. 38: 700-702.

DOYLE, M. P., CHAPMAN, B., HU, W., PETERSON, C. S, McKERVEY, M. A. and GARCIA, C. F. 1999d. Catalytic Intramolecular Addition of Metal Carbenes to Remote Furans. Org. Lett. 1, pp 1327-1329.

DOYLE, M. P., HU, W., CHAPMAN, B., MARNETT, A. B., PETERSON, C. S., VITALE, J. P. and STANLEY, S. A. 2000. Enantiocontrolled Macrocycle Formation by Catalytic Intramolecular Cyclopropanation. J. Am. Chem. Soc. 122: $5718-5728$.

ENE, D. G. and DOYLE, M. P. 1998. Recent Advances in Asymmetric Catalytic Metal Carbene Transformations. Chim. Oggi. pp 37-38.

ESTEVAN, F., LAHUERTA, P., PÉREZ-PRIETO, J., STIRIBA, S.-H. and UBEDA, M. A. 1995. New Rhodium(II) Catalysts for Selective Carbene Transfer Reactions. Synlett. pp 1121-1122.

GARCIA, C. F., McKERVEY, M. A. and YE, T. 1996. Asymmetric Catalysis of Intramolecular N-H Insertion Reactions of $\alpha$-Diazocarbonyls. J. Chem. Soc., Chem. Commun. pp 1465-1466.

GAWLEY, R. E. and AUBÉ, J. 1996. Tetrahedron Organic Chemistry Series Vol. 14 : Principles of Asymmetric Synthesis. Pergamon, Oxford.

HASHIMOTO, S., WATANABE, N. and IKEGAMI, S. 1990. Enantioselective Intramolecular C-H Insertion of $\alpha-$ Diazo $\beta$-Keto Esters Catalysed by Homochiral Rhodium(II) Carboxylates. Tetrahedron Lett. 31: 5173-5174.

HASHIMOTO, S., WATANABE, N. and IKEGAMI, S. 1994. Enantioselective Intramolecular C-H Insertion Reactions of $\alpha$-Diazo- $\beta$-Keto Esters Catalysed by Dirhodium(II) Tetrakis[ $N$-phthaloyl-(S)-phenylalaninate]: The Effect of the Substituent at the Insertion Site on Enantioselectivity. Synlett. pp 353-355.

HO, T.-L. 1988. Carbocycle Construction in Terpene Synthesis. VCH, New York. Chap. 10, pp 516-531.

HODGSON, D. M., STUPPLE, P. A. and JOHNSTONE, C. 1997. Catalytic Enantioselective Tandem Carbonyl Ylide Formation-Cycloaddition. Tetrahedron Lett. 38: 6471-6472.

HUDLICKY, T., KUTCHAN, T. M. and NAQVI, S. M. 1985. Org. React. 33: 247-335.

HUSBANDS, S., SUCKLING, C. A. and SUCKLING, C. J. 1994. Latent Inhibitors. Part 10. The Inhibition of Carboxypeptidase A by Tetrapeptide Analogs Based on 1-Aminocyclopropane Carboxylic Acid. Tetrahedron. 50: 9729-9742.

ISHITANI, H. and ACHIWA, K. 1997. Synthesis of an Axially Dissymmetric Biphenylcarboxylate Ligand, BDME, and Asymmetric Cyclopropanation of Olefins with Diazoacetate by its Dirhodium(II) Complex. Synlett. pp 781-782. 


\section{DIRHODIUM(II) CARBENES: THE CHIRAL PRODUCT CASCADE}

JACOBSEN, E. N., PFALTZ, A. and YAMAMOTO, H (Eds). 1999. Comprehensive Asymmetric Catalysis. SpringerVerlag, Heidelberg.

KENNEDY, M., McKeRVEY, M. A., MAGUIRE, A. R. and ROOS, G. H. P. 1990a. Asymmetric Synthesis in Carbon-Carbon Bond Forming Reactions of $\alpha$-Diazoketones Catalysed by Homochiral Rhodium(II) Carboxylates. J. Chem. Soc., Chem. Commun. pp 361-362.

KITAGAKI, S., MATSUDA, H., WATANABE, N. and HASHIMOTO, S. 1997. Highly Enantioselective Intermolecular Cyclopropanation Catalysed by Dirhodium(II) Tetrakis[3(S)-phthalimido-2-piperidinonate]: Solvent Dependency of the Enantioselection. Synlett. pp 1171-1174.

KITIGAKI, S., ANADA, M., KATAOKA, O., MATSUNO, K., UMEDA, C., WATANABE, N. and HASHIMOTO, S. 1999. Enantiocontrol in Tandem Carbonyl Ylide Formation and Intermolecular 1,3-Dipolar Cycloaddition of $\alpha$-Diazo Ketones Mediated by Chiral Dirhodium(II) Carboxylate Catalyst. J. Am. Chem. Soc. 121: 1417-1418.

LANDAIS, Y. and PLANCHENAULT, D. 1994a. Asymmetric Metal Carbene Insertion into the Si-H Bond. Tetrahedron Lett. 35: 4565-4568.

LANDAIS, Y., PLANCHENAULT, D. and WEBER, V. 1994b. Rhodium(II) Vinylcarbenoid Insertion into the Si-H Bond. A New Stereospecific Synthesis of Allylsilanes. Tetrahedron Lett. 35: 9549-9552.

LANDAIS, Y. 1997. Carbene and Metal-Carbenoid Insertion into the Silicon-Hydrogen Bond. Main Group Chem. News. 5, pp 20-29.

MAAS, G. 1987. Transition-Metal Catalysed Decomposition of Aliphatic Diazo Compounds - New Results and Applications in Organic Synthesis. Top. Curr. Chem. 137: 76-253.

MARTIN, S. F., OALMANN, C. J. and LIRAS, S. 1992a. Enantioselective, Rhodium Catalyzed Intramolecular Cyclopropanations of Homoallylic Diazoacetates. Tetrahedron Lett. 33: 6727-6730.

MARTIN, S. F., AUSTIN, R. E., OALMANN, C. J., BAKER, W. R., CONDON, S. L., DeLARA, E., ROSENBERG, S. H., SPINA, K. P., STEIN, H. H., COHEN, J. and KLEINERT, H. D. 1992b. 1,2,3-Trisubstituted Cyclopropanes as Conformationally Restricted Peptide Isosteres. Application to the Design and Synthesis of Novel Renin Inhibitors. J. Med. Chem. 35: 1710-1721.

MARTIN, S. F., OALMANN, C. J. and LIRAS, S. 1993. Cyclopropanes as Conformationally Restricted Peptide Isosteres. Design and Synthesis of Novel Collagenase Inhibitors. Tetrahedron. 49: 3521-3532.

MARTIN, S. F. and HILLIER, M. C. 1998. Diastereodifferentiation in Intramolecular Cyclopropanation of Chiral Secondary Allylic Diazoacetates. Tetrahedron Lett. 39: 2929-2932.

McCARTHY, N., McKERVEY, M. A., YE, T., McCANN, M., MURPHY, E. and DOYLE, M. P. 1992. A New Rhodium(II) Phosphate Catalyst for Diazocarbonyl Reactions Including Asymmetric Synthesis. Tetrahedron Lett. 33: 5983-5986.

McKERVEY, M. A. and YE, T. 1992. Asymmetric Synthesis of Substituted Chromanones via C-H Insertion Reactions of $\alpha$-Diazoketones Catalysed by Homochiral Rhodium(II) Carboxylates. J. Chem. Soc., Chem. Commun. pp 823-824.

MILLER, D. J., MOODY, C. J. and MORFITT, C. N. 1999. Diastereoselectivity in the O-H Insertion Reactions of Carbenoids Derived from Phenyldiazoacetates. II. Comparison of Rhodium(II)- and Acid-Mediated Reactions. Aust. J. Chem. 52: 97-107.

MUKAIYAMA, T., YAMASHITA, H. and ASAMI, M. 1983. An Asymmetric Synthesis of Bicyclic Lactones and its Application to the Asymmetric Synthesis of $(1 R, 3 S)$-cis-Chrysanthemic Acid. Chem. Lett. pp 385-388.

MÜLlER, P. and POLLEUX, P. 1994. Enantioselective Formation of Bicyclic Lactones by Rhodium-Catalyzed Intramolecular C-H Insertion Reactions. Helv. Chim. Acta. 77: 645-654.

MÜller, P., BAUD, C., ENE, D., MOTALlEBI, S., DOYLE, M. P., BRANDES, B. D., DYATKIN, A. B. and SEE, M. M. 1995. Enantioselectivity and cis/trans-Selectivity in Dirhodium(II)-Catalysed Addition of Diazoacetates to Olefins. Helv. Chim. Acta. 78: 459-470.

NEFEDOV, O. M., SHAPIRO, E. A. and DYATKIN, A. B. 1992. Diazoacetic Acids and Derivatives. In Supplement B: The Chemistry of Acid Derivatives. (Ed). Patai, SWiley, New York.

NEWCOMB, M. and CHESTNEY, D. L. 1994. A Hypertensive Mechanistic Probe for Distinguishing between Radical and Carbocation Intermediates. J. Am. Chem. Soc. 116: 9753-9754.

PADWA, A., KRUMPE, K. E., GAREAU, Y. and CHIACCHIO, U. 1991. Rhodium(II)-Catalyzed Cyclisation Reaction of Alkynyl-Substituted $\alpha$-Diazo Ketones. J. Org. Chem. 56: 2523-2530.

PADWA, A. and KRUMPE, K. E. 1992. Application of Intramolecular Carbenoid Reactions in Organic Synthesis. Tetrahedron. 48: 5358-5453. 
PADWA, A., AUSTIN, D. J., GAREAU, Y. KASSIR, J. M. and XU, S. L. 1993. Rearrangement of Alkynyl and Vinyl Carbenoids via the Rhodium(II)-Catalyzed Cyclization Reaction of $\alpha$-Diazo Ketones. J. Am. Chem. Soc. 115: $2637-2647$.

PADWA, A. and AUSTIN, D. J. 1994. Ligand Effects on the Chemoselectivity of Transition Metal Catalysed Reactions of $\alpha$-Diazo Carbonyl Compounds. Angew. Chem. Int. Ed. Engl. 33: 1797-1815.

PAULISSENEN, R., REIMLINGER, H., HAYEZ, E., HUBERT, A. J. and TEYSSIE, Ph. 1973. Transition Metal Catalysed Reactions of Diazocompounds - II. Insertion in the Hydroxylic Bond. Tetrahedron Lett. pp 22332236.

PIERSON, N., FERNÁNDEZ-GARCIÁ, C. and McKERVEY, M. A. 1997. Catalytic Asymmetric Oxonium Ylide[2,3] Sigmatropic Rearrangement with Diazocarbonyl Compounds: First Use of $\mathrm{C}_{2}$-Symmetry in $\mathrm{Rh}(\mathrm{II})$ Carboxylates. Tetrahedron Lett. 38: 4705-4708.

PIRRUNG, M. C. and ZHANG, J. 1992. Asymmetric Dipolar Cycloaddition Reactions of Diazo-Compounds Mediated by a Binaphtholphosphate Rhodium Catalyst. Tetrahedron Lett. 33: 5987-5990.

RAPPOPORT, Z. (Ed.) 1987. The Chemistry of the Cyclopropyl Group, Parts 1 and 2. Wiley, New York.

REGITZ, M. and MAAS, G. 1986. Diazo Compounds: Properties and Synthesis. Academic Press, Orlando.

REISSIG, H.-U. 1995. Formation of C-C Bonds by [2+1] Cycloaddition. In Stereoselective Synthesis of HoubenWeyl Methods of Organic Chemistry. Vol. 21c. Eds Helmchen, G., Hoffmann, R. W., Mulzer, J. and Schaumann, E. Georg Thieme Verlag, New York.

ROGERS, D. H., YI, E. C. and POULTER, C. D. 1995. Enantioselective Synthesis of (+)-Presqualene Diphosphate. J. Org. Chem. 60: 941-945.

ROOS, G. H. P. and McKERVEY, M. A. 1992. A Facile Synthesis of Homochiral Rh(II) Carboxylates. Synth. Commun. 22: 1751-1756.

ROOS, G. H. P. and RAAB, C. E. 1997. Asymmetric Carbene Transformations. In Advances in Catalytic Processes, Vol. 2. Ed. M. P. Doyle. JAI Press, London.

ROOS, G. H. P., RAAB, C. E., EMSLIE, N. D., DOYLE, M. P. and LYNCH, V. 1998. Synthesis, Structure and Reactivity of a Novel Series of Diastereomeric Dirhodium(II) Tetracarboxamidates. Catalysts for Asymmetric Diazoacetate Transformations. Aust. J. Chem. 51: 1-8.

SALAÜN, J. 1989. Optically Active Cyclopropanes. Chem. Rev. 89: 1247-1270.

SEYDEN-PENNE, J. 1995. Chiral Auxiliaries and Ligands in Asymmetric Synthesis. Wiley, New York.

SCHOTTEN, T., BOLAND, W. and JAENICKE, L. 1986. Enantioselective Synthesis of Dictyopterene C, 6R-(-)Butyl-2,5-cycloheptadiene. The Pheromone of Several Dictyotales (Phaeophyceae). Tetrahedron Lett. 27: 2349-2352.

SIlVERMAN, R. A., DING, C. Z., BORRILlO, J. L. and CHANG, J. T. 1993. Mechanism-Based Enzyme Inactivation via a Diactivated Cyclopropane Intermediate. J. Am. Chem. Soc. 115: 2982-2983.

SINGH, V. K., DATTAGUPTA, A. and SEKAR, G. 1997. Catalytic Enantioselective Cyclopropanation of Olefins Using Carbenoid Chemistry. Synthesis. pp 137-149.

SUCKLING, C. J. 1988. The Cyclopropyl Group in Studies of Enzyme Mechanism and Inhibition. Angew. Chem., Int. Ed. Engl. 27: 537-552.

SUGA, H., ISHIDA, H. and IBATA, T. 1998. Stereocontrol of Metal-Catalyzed Cycloaddition of Carbonyl Ylide with N-Substituted Maleimide. Tetrahedron Lett. 39: 3165-3166.

SUGIMURA, T., NAGANO, S. and TAI, A. 1998. The First Asymmetric Synthesis of Optically Active Tropilidenes. High Regio- and Diastereo-Differentiating Addition of Diazo Ester to Aromatic Ring Using 2,4-Pentanediol as Chiral Linking Bridge. Chem. Lett. pp 45-46.

TABER, D. F., RAMAN, K. and GAUL, M. D. 1987. Enantioselective Ring Construction: Synthesis of (+)-Estrone Methyl Ether. J. Org. Chem. 52: 28-34.

TABER, D. F. 1991. Carbon-Carbon Bond Formation by C-H Insertion. In Comprehensive Organic Synthesis: Selectivity, Strategy, and Efficiency in Modern Organic Chemistry. Eds B. M. Trost and I. Fleming. Pergamon Press, New York, Vol. 3, Chapter 4.2.

TABER, D. F. and MALCOLM, S. C. 1998. Rhodium-Mediated Intramolecular C-H Insertion: Probing the Geometry of the Transition State. J. Org. Chem. 63: 3717-3721.

TABER, D. F., MALCOLM, S. C., PÉREZ-PRIETO, J. and ANGELES MONGE, M. 1999. Synthesis, Structure, and Reactivity of the First Enantiomerically Pure Ortho-Metalated Rhodium(II) Dimer. J. Am. Chem. Soc. 121: $860-861$ 


\section{DIRHODIUM(II) CARBENES: THE CHIRAL PRODUCT CASCADE}

TANIMORI, S., TSUBOTA, M., HE, M. and NAKAYAMA, M. 1997. A Concise Enantioselective Pathway to Carbocyclic Nucleoside: Asymmetric Synthesis of Carbocyclic Moiety of Carbovir. Synth. Commun. 27, pp 2371-2378.

WANG, P. and ADAMS, J. 1994. Model Studies of the Stereoelectronic Effect in Rh(II) Mediated Carbenoid C-H Insertion Reactions. J. Am. Chem. Soc. 116: 3296-3305.

WATANABE, N., OHTAKE, Y., HASHIMOTO, S., SHIRO, M. and IKEGAMI, S. 1995. Asymmetric Creation of Quaternary Carbon Centers by Enantiotopically Selective Aromatic C-H Insertion Catalysed by Chiral Dirhodium(II) Carboxylates. Tetrahedron Lett. 36: 1491-1494.

WATANABE, N., OGAWA, T., OHTAKE, Y., IKEGAMI, S. and HASHIMOTO, S. 1996a. Dirhodium(II) Tetrakis[N-phthaloyl-(S)-tert-leucinate]: A Notable Catalyst for Enantiotopically Selective Aromatic Substitution Reactions of $\alpha$-Diazocarbonyl Compounds. Synlett. pp 85-86.

WATANABE, N., MATSUDA, H., KURIBAYASHI, H. and HASHIMOTO, S. 1996b. Dirhodium(II) Tetrakis[3(S)Phthalimido-2-Piperidinonate]: A Novel Dirhodium(II) Carboxamidate Catalyst for Asymmetric Cyclopropanation. Heterocycles. 42: 537-542.

WEE, A. G. H. and LIU, B. S. 1996. The $\mathrm{Rh}_{2}(\mathrm{OAc})_{4}$ Catalysed Insertion in Chiral Ester Diazoanilides. Tetrahedron Lett. 37: 145-148.

WONG, H. N. C., HON, M.-Y., TSE, C.-W., YIP, Y.-C., TANKO, J. and HUDLICKY, T. 1989. Use of Cyclopropanes and Their Derivatives in Organic Synthesis. Chem. Rev. 89: 165-198.

YE, T. and McKERVEY, M. A. 1994. Organic Synthesis with $\alpha$-Diazocarbonyl Compounds. Chem. Rev. 94: 10911160.

Received 29 January 2000

Accepted 28 August 2000 